\title{
A Comparative Study on the Protective Role of Silymarin and Coenzyme-Q10 on the Cerebellar Cortex of Experimentally Induced Atherosclerosis in Adult Male Albino Rats: A Histological, Original Immunohistochemical and Biochemical Study
} Article

\author{
Nadia Said Badawy Khair and Seham Ahmed Mohammed Abdel Aziz \\ Department of Histology and Cell Biology, Faculty of Medicine, Menoufia University, \\ Menoufia, Egypt
}

\begin{abstract}
Background: Atherosclerosis is known as a serious cardiovascular condition that causes human mortality worldwide. Atherosclerosis is a significant progressive condition of inflammation. Atherosclerosis of the cerebellar arteries affects voice, balance and fine motor control. Coenzyme-Q10 vitamin soluble in fat that used for heart failure and angina treatment protocol. It has the potential to influence cellular bioenergetics, and counteract free radical damage. This has proven success in treating many neurodegenerative diseases. Silymarin is a flavonoid extract of the herb Silybum marianum. It has been reported as the gold medicine in liver disorders and evaluated recently as a neuroprotective.

Objective: Comparison of potential neuroprotective effects of Co Q10 and Silymarin on adult male albino rats cerebellar cortex suffering from atherosclerosis.

Materials and Methods: Sixty adult male albino rats were divided randomly into equal four classes: Group I (control group) subdivided into three subgroups: Subgroup IA: provided ordinary diet. Subgroup IB (Co enzyme Q10 treated): obtained ordinary diet and co-enzyme Q10 Subgroup IC (Silymarin treated): obtained ordinary diet and Silymarin. Group II (atherosclerotic group), Group III (atherosclerotic Co Q10 treated group) and Group IV (atherosclerotic Silymarin treated group). After three months, lipid profile was assessed in blood samples taken from all classes. Cerebellar cortices were processed for histological, biochemical, immunohistochemical and electron microscopic studies.

Results: Atherosclerotic rats showed loss and disruption of Purkinje cell layer with pyknotic nuclei, dilated cisternae of rough endoplasmic reticulum, prominent perineural spaces and spongiosis of granular and molecular layers. Significant increase in GFAP, Cox-2 immunoreactivity was also found. However, concomitant administration of Co Q10 or Silymarin had ameliorating effect on these changes.

Conclusion: Co Q10 or Silymarin supplementation had a neurological protective role in atherosclerosis. Silymarin may be the ideal neuroprotective agent and new approach for reduction of many neurological diseases in high risk population.
\end{abstract}

Received: 26 May 2020, Accepted: 06 July 2020

Key Words: Atherosclerosis, coenzyme-Q10, purkinje cells, silymarin, spongiosis.

Corresponding Author: Nadia Said Badawy Khair, MD, Department of Histology and Cell Biology, Faculty of Medicine, Menoufia University, Menoufia, Egypt, Tel.: +204 83400449, E-mail: amarsmile2007@yahoo.com

ISSN: 1110-0559, Vol. 44, No.2

\section{INTRODUCTION}

Atherosclerosis (AS) is one of the cardiovascular conditions, causing mortality worldwide ${ }^{[1]}$. This is a progressive inflammatory disease that causes vessel wall plaques to form; hinders the resulting supply of blood to the tissues $^{[2]}$. These plaques can remain silent for many decades, but may cause stenosis or rupture over time, leading to heart failure, myocardial infarction and stroke $\mathrm{e}^{[3]}$. Although, AS is a multi-factorial disorder, elevated cholesterol concentrations, transmitted primarily by LDL-C particles, facilitate atherosclerotic lesions ${ }^{[4]}$.

Ischemic cerebrovascular diseases (CVDs) and its complications are one of world's most incipient reasons of morbidity and mortality. It leads to cognitive decline and vascular dementia. Studies have shown that atherosclerotic disease is the cause of the ischemic $\mathrm{CVDs}^{[5]}$.
In the presence of elevated plasma low-density lipoprotein (LDL), plaques within the cranial arteries will build up. As a consequence, luminal stenosis can reduce or even block the blood supply to the brain, causing deficiencies of oxygen and energy substrates in the cerebral and cerebellar tissues ${ }^{[6]}$. Control voice, fine motor coordination, and memory are impaired by cerebellar atherosclerotic arteries ${ }^{[7]}$.

Coenzyme-Q10 (CoQ10), (2,3dimethoxy-5methyl6decarpenyl benzoquinone) is a vitamin-like fat soluble quinine generally referred to ubiquinone. It is found throughout the body in various tissues, particularly in the skin, liver, kidney and pancreas ${ }^{[8]}$. This is consumed in meats and fish, in limited quantities. It is widely used in treatment of angina and heart failure. CoQ10 has also been used to alleviate headache with migraine, Parkinson's disease and other disorders $^{[9]}$. It has an antioxidant function, which plays 
a significant role in the metabolism and can affect cellular bioenergetics and mitigate the free radical damage ${ }^{[10]}$.

Silymarin (SM) is a flavonoid extract of a plant called Silybum Marianum. This is a lipophilic fruit extract and milk thistle's active complex ${ }^{[11]}$. SM is formulated as a mixture of flavonolignan antioxidants. It is composed of four isomers of flavonolignan; silybin, sosilybin, silydianin and silychristin. Silybin is amongst them the most active and the most widely used ${ }^{[12]}$. Silymarin is consumed orally and is excreted as sulphates and conjugates primarily by bile. It has been identified as the gold drug for treatment of alcoholic hepatitis-related liver disorders and viral hepatitis ${ }^{[13]}$.

In addition to hepato-protection, many neurodegenerative lesions, as cerebral ischemia ${ }^{[14]}$, Parkinson's disease ${ }^{[11]}$ and Alzheimer's disease ${ }^{[15]}$ have recently been confirmed that SM a neuroprotective medication for treatment. This also exhibits additional benefits by affecting processes such as amyloid accumulation and apoptotic cellular machinery ${ }^{[16]}$.

It is well-known that the cerebellum control both posture and motion. Disorders of the cerebellum have an effect on muscle function and hinder body coordination. Also, it is found in other non-motor cognitive functions, as learning, sensory perception, memory and attention ${ }^{[17]}$. Only a few studies have identified the effect of atherosclerosis (AS) on the cerebellum and on the clinical level. So, the present work aimed to study the structural changes which might result from induced atherosclerosis on the cerebellar cortex of adult male albino rats. Also to compare the possible neuroprotective effects of Co Q10 versus Silymarin in adult male albino rats, suffering from atherosclerosis, using histological, biochemical and immunohistochemical studies.

\section{MATERIALS AND METHODS}

The present study was carried out on sixty adult male albino rats, average age of 2-3 months and weighing 180-200 gms each. They had been installed in stainless steel in a room at standard temperature. They were allowed free access to ad-libitum water and rat chow throughout the experiment. Strict sanitation and precautions have been taken to keep them in a safe, natural climate. The animals were observed daily for general condition and behavior. Animal care was based on ethical guidelines accepted by the Menoufia Faculty of Medicine Ethical Committee.

\section{Experimental procedure}

The animals were divided into fourgroups, 15 animalseach: Group I (control group): it was consisted of 15 adult rats that was subdivided equally into three subgroups:

Subgroup IA: animals were left untreated and provided an ordinary diet.

Subgroup IB (Co enzyme Q10 treated): each rat obtained an ordinary diet and co-enzyme Q10 at a dose of $1 \mathrm{mg}$ by oral gavage ${ }^{[10]}$. Co enzyme Q10 (Ubiquinone): $200 \mathrm{mg}$ bottle in liquid form was obtained from Pharco Pharmaceutical Company (Cairo, Egypt).
Subgroup IC (Silymarin treated): each rat obtained an ordinary diet and Silymarin powder dissolved in sterile water and taken orally with a dosage of $100 \mathrm{mg} / \mathrm{kg}$ body weight through the gastric tube ${ }^{[1]}$. Silymarin powder obtained from sigma-Aldrich, USA

Group II (atherosclerotic induced group): received an ordinary diet with $1 \%$ cholesterol powder for three months to induce ${ }^{[18]}$. Cholesterol powder (3 $\beta$-Hydroxy-5-cholestene) from Sigma Aldrich Co., Germany, developed cholesterol powder (approximately 99\%) and catalog number (57-88-5): $100 \mathrm{~g}$ in a polycontainer.

Group III (atherosclerotic Co Q10 treated group): Received an ordinary diet with $1 \%$ cholesterol powder in the same dose and route of administration of group II, concomitant with Co-enzyme-Q 10 in the same dose and route of administration of subgroup IB.

Group IV (atherosclerotic Silymarin treated group): each rat provided an ordinary diet with $1 \%$ cholesterol powder in the same dose and route of administration of group II, simultaneously with Silymarin in the same dose and route of administration of subgroup IC.

The rats were fed their respective diets for three months and had water ad libitum. Experimental animals' body weights were assessed at the beginning of the experiment, and after 3 months. They were fasted for $10 \mathrm{~h}$ at end of experiment but water was not limited.

At the appropriate time, all rats were anaesthetized and perfused transcardiac with $4 \%$ paraformaldehyde in $0.1 \mathrm{M}$ PBS (phosphate buffered saline) followed by $4 \%$ cold paraformaldehyde in $0.1 \mathrm{M}$ PBS for $10 \mathrm{~min}^{[19]}$. Blood samples obtained from orbital venous plexus, centrifuged for $20 \mathrm{~min}$. Carefully opened the skulls and separated cerebelli, then dissected cerebellar cortices. Specimens of cerebellar cortices postfixed in 10 per cent of formalin buffered for light microscopic analysis. Other specimens, postfixed for ultrastructural examination in 2.5 per cent phosphatebuffered glutar-aldehyde. For biochemical analysis of tissue, sections of cerebellar cortices are stored in liquid nitrogen for the assessment of endogenous antioxidant and oxidative markers.

\section{Histological study}

Tissue samples for light microscopic analysis were then washed and processed for preparation of paraffin section. Sections were cut and stained with hematoxylin and eosin (H\&E) for histological examination ${ }^{[20]}$.

\section{Immunohistochemical study}

Glial fibrillary acidic protein immunostaining (GFAP) for detection of astrocytes Sections of paraffin were deparaffinised, rehydrated and endogenous peroxidase activity blocked in absolute alcohol for $45 \mathrm{~min}$ with 0.05 per cent hydrogen peroxide. In order to reveal the antigen sites, the slides were placed in (PBS) for $7 \mathrm{~min}$, and were put in a microwave with citrate buffer for $10 \mathrm{~min}$. In bovine serum albumin, the slides were incubated in PBS dissolved for 30 
min to avoid unspecific staining of the history. Then, the parts were incubated for 90 min with the primary antibodies Antibody GFAP has been put to the pieces. Slides were rinsed in PBS, incubated with anti-mouse immunoglobulins for $60 \mathrm{~min}$, combined with a peroxidase-labeled dextran polymer ${ }^{[21]}$. Control negative parts treated by with PBS, with all other steps being carried out in the same way. Normal brain was used to regulate the GFAP positively ${ }^{[21]}$.

\section{PCNA immunohistochemicalstaining}

Nuclear proliferating cell antigen (PCNA) ,an intranuclear polypeptide included in replication, repair and excision of DNA. Cell proliferation is related to its synthesis and expression ${ }^{[22]}$. In PCNA (Clone PC 10, DAKO A / S Denmark), immunohistochemical staining was performed using primary antiserum. In Trisbufferd saline the primary antibody was diluted with a dilution of $1: 50$, as defined by the data sheet. The parts incubated in $+4{ }^{\circ} \mathrm{C}$ overnight with the primary antibody. Its binding was observed using a generic, manufacturer-recommended avidin biotin-peroxidase detection method (DAKO, Carpenteria, USA). Instead of the primary antibody a mouse monoclonal antibody was added to serve as a negative buffer. Small intestines have been used for effective regulation. Then the slides were stained with diaminobenzene (DAB) as the chromogenic, counterstained with hematoxylin ${ }^{[22]}$.

\section{Cyclooxygenase-2 (Cox-2) immunohistochemical staining}

COX-2 expression was observed by using the main antirabbit antibody, COX2-specific anti-mouse polyclonal $\mathrm{IgG}$ (SAB4200576; Sigma). Parts of the cerebellar cortices were dewaxed, hydrated and endogenous peroxidase activity was blocked in methanol with 0.3 per cent hydrogen peroxide. In antibody diluent (Cat. \# IW-1000 or \# IW-1001), the primary antibody parts incubated for $1 \mathrm{~h}$ at room temperature. Parts have been rinsed with PBS 3 times. Applied hydrogen peroxide covers the section for $5 \mathrm{~min}$, and slides were gently putin PBS.Adequate volume of primary antibody (dilution 1: 200) was added to the specimens, which were incubated afterwards. The slides were then rinsed into PBS. Biotinylated connection has been placed and parts have been rinsed with PBS. Streptavidin horseradish peroxidase reagent, sprayed for $10 \mathrm{~min}$, then rinsed in PBS. Freshly prepared 3, 3'- diaminobenzidine chromogenic substrate solution was placed on the specimens for $10 \mathrm{~min}$. Sections then sprayed with distilled water and counterstained with Mayer's hematoxyline after being dried, dehydrated, cleaned and placed by DPX in tap water.Save for the use of the primary antibody ${ }^{[23]}$, negative tests were treated as the same procedure. Parts prepared from control animal kidney tissue were used as positive COX-2 test slides ${ }^{[23]}$.

\section{Electron microscopic study}

Cerebellar parts $(1 \mathrm{~mm} 3)$ were cut ,fixed in 3 per cent glutaraldehyde with $0.1 \mathrm{~mol} / 1 \mathrm{PBS}$ at $4{ }^{\circ} \mathrm{C}$ for transmission electron microscope (TEM) analysis. Parts were dehydrated in ethanol, purified in propylene oxide, coated with epon. Semi-thin parts of toluidine blue were cut and dyed in. Parts of ultrathin had been cut and treated with uranyl acetate and lead citrate ${ }^{[24]}$. A Jeol- JEM- 100 CXII; Joel, Tokyo, Japan, studied the ultra-structure of the tissues. TEM processing and analysis were performed at the Unit of Electron Microscopy, Faculty of Medicine, Tanta University.

\section{Biochemical study}

Blood samples obtained from orbital venous plexus, centrifuged for $20 \mathrm{~min}$ then blood sera used to triglyceride, total cholesterol, LDL-cholesterol and HDL cholesterol, determinations. The spectrophotometer was used to calculate both of these parameters. Cortices of cerebellum were excised, immersed in liquid nitrogen to freeze for $1 \mathrm{~h}$ at $-70{ }^{\circ} \mathrm{C}$. In ice cold phosphate buffer, frozen tissue was homogenized and centrifuged. The supernatant was used as the antioxidant markers to test tissue superoxide dismutase $(\mathrm{SOD})^{[25]}$ and catalase $(\mathrm{CAT})^{[26]}$. They were determined using commercial kits (Bio Diagnostic Company, Dokki, and Giza, Egypt, respectively) ,catalog no. 2520, 2516. Malodialdehyde concentration (MDA) has been calculated as an indicator of lipid peroxidation and oxidant stress ${ }^{[27]}$.

\section{Morphometric study and Statistical analysis}

The interactive image analyzer measurement menu (LeciaQwin 500 image analyser computer program, England) in the Department of Anatomy, Faculty of Medicine, University of Menoufia, used to test these parameters in all studied classes.

1. Counting the nuclei of Purkinje cells by millimeter length in the segment ${ }^{[28]}$

2. Immunostaining strength of GFAP and Cox-2 was assessed in immunostained areas. All of the above parameters were calculated by total magnification of $\times 400$ using 10 readings from 5 non-overlapped sections from each rat of 5 rats randomly selected. The biochemical and morphometric results were analyzed and compared by student's t-test. $P$-value for the significant change in each parameter in the experimental animals to check according to control group. Data were tabulated as mean $\pm \mathrm{SD}$, analyzed using statistical (SPSS) software (version 17.0 on an IBM compatible computer; SPSS Inc., Chicago, Illinois, USA). $P$ value was calculated at $0.05, P>0.05$ was non-significant, while $P$ value $<0.05$ significant and $\mathrm{P}$ value $<0.001$ was highly significant ${ }^{[29]}$.

\section{RESULTS}

\section{General appearance and survival}

Observation of rats during the experimental period revealed that high cholesterol diet was well tolerated by the rats and no mortality was detected. Rats of all groups exhibited normal activities. They had smooth and glossy fur and did not have any neurological signs. 


\section{Mean weight in grams in different groups}

At the end of the experiment, there was a highly significant increase $(p<0.001)$ in the mean weight of atherosclerotic rats (group II) comparing with the control groups. There was a significant decrease $(P<0.05)$ in the mean weight in atherosclerotic Co Q10 treated group (group III) as compared with atherosclerotic group. In addition, atherosclerotic Silymarin treated rats(group IV) showed a highly significant decrease $(p<0.001)$ in the mean weight when compared to atherosclerotic rats (group II) (Table 1).

\section{Histological results}

H\&E sections of the cerebellum of group (I) showed the well-known normal structure. Each cerebellar folium consisted of outer gray matter (cerebellar cortex) and inner white matter. The cerebellar cortices of animals of subgroups IA, IB and IC showed the normal histological architecture of the rat cerebellar cortex with no difference between them. Each cortex is formed of outer molecular, middle Purkinje cell layer, inner granular layer (Figure 1). The Molecular layer formed mainly of fibers, stellate and basket cells. The Purkinje cells were arranged in a single row between the molecular and granular layers. The inner granular layer showed aggregation of small tightly packed cells with dark spherical nuclei among pale areas, called cerebellar islands. Small blood capillaries were also seen in this layer (Figure 2). Purkinje cells showed large pyriform cell bodies containing large rounded vesicular nuclei with prominent nucleoli and pale acidophilic cytoplasm with scattered basophilic Nissl granules. The granular layer formed of numerous crowded small granular cells with darkly stained nuclei and scanty cytoplasm (Figure 3). H\&E stained cerebellar sections of atherosclerotic group (group II) revealed disruption of the Purkinje cell layer. Most of Purkinje cells were shrunken having irregular outlines with deep homogenous cytoplasm with absence of Nissl granules and having darkly stained pyknotic nuclei. Other Purkinje cells were lost, leaving empty spaces, surrounded by neuroglia cells. Regular stellate and basket cells and congested dilated blood vessels were also noticed in the molecular layer (Figures 4,5). There were prominent perineural spaces around Purkinje, basket and stellate cells. Numerous vacuolations in the granular and molecular layers (Spongiosis) were also noticed (Figure 5).

On the other hand, group III analysis (atherosclerotic coenzyme Q10 treated) showed that most Purkinje cells had a similar appearance to control group appearance. however, some Purkinje cells still affected. The granular layer was apparently normal However, slight vacuolations in the molecular layer were still present (Figure 6).

H\&E stained cerebellar portions of atherosclerotic Silymarin treated rats (group IV) showed the cortical layers looking more or less as in control group. Purkinje cells retained their normal linear organization. They contained pale vesicular nuclei and prominent nucleoli. The granule cells appear nearly similar to the control. No observable differences from control group were noticed in the granular and molecular layers (Figure 7). In addition, Purkinje cells retained its normal shape and size (Figure 8).

Electron microscopic examination of the cerebellar cortices of control rats revealed normal Purkinje cells with its characteristic large size. They had euchromatic nuclei with prominent nucleoli. Their cytoplasm had mitochondria, lysosomes, free ribosomes and strands of rough endoplasmic reticulum (Figure 9). Electron microscopic examination of granular layer of control group, revealed that granule cells had rounded nuclei having peripheral clumps of heterochromatin, free ribosomes and mitochondria (Figure 10).

Ultrathin sections of the molecular layer of cerebellar cortex of control rats showed that, almost all nerve fibers are surrounded by normal myelin sheath and having mitochondria (Figure 11). Cerebellar cortices of both Co Q10 and Silymarin-treated rats demonstrated no ultrastructural difference from control group.

Cerebellar sections of atherosclerotic rats showed a shrunken Purkinje cell having flat indented nucleus, dilated cisternae of rough endoplasmic reticulum, cytoplasmic vacuoles and many electron dense vesicles (Figure 12). Granule cells contained increased nuclear chromatin condensation, free ribosomes destructed mitochondria with disruption of myelinated nerve fibers (Figure 13). In addition, some granule cells had small pyknotic nuclei with areas of vacuolated cytoplasm (Figures 13,14), while other cells were apoptotic with presence of vascular congestion (Figure 14). The molecular layer showed disruption and dissociation of the myelinated nerve fibers with degenerated mitochondria in some fibers (Figure 15). Electron microscopic examination of the cerebellar cortex of atherosclerotic rats treated with co Q10 revealed Purkinje cell having euchromatic nucleus with apparent nucleolus, cisternae of rough endoplasmic reticulum, numerous small ribosomes.

However, degenerated mitochondria and some cytoplasmic vacuoles are still present (Figure 16). Nearly normal granule cells, having rounded nuclei and surrounded by a shell of cytoplasm were seen. Other cells with increased nuclear chromatin condensation and dilated cisternae of rough endoplasmic reticulum. The mylinated nerve fibers surrounded the cells, were more or less normal (Figure 17). The molecular layer contained nearly intact normal mylinated nerve fibers. While, few myelinated nerve fibers with slight distortion of its myelin sheath were still present (Figure 18).

In atherosclerotic Silymarin-treated group (group IV), Purkinje cells exhibited similar ultrastructural appearance of the control; euchromatic nuclei, prominent nucleoli and well-defined nuclear envelope. Cytoplasm containing free ribosomes, mitochondria and rough endoplasmic reticulum (Figure 19). The granular cells appeared more or less normal and showed round or oval nuclei and peripheral masses of heterochromatin, mitochondria and free ribosomes (Figure 20). Mylinated nerve fibers were nearly like of control group (Figures 20,21 ). 


\section{Immunohistochemical results}

GFAP immunohistochemical staining (astrocyte detection) of cerebellar cortices of control rats, Co Q10 and Silymarin -treated rats showed scattered GFAP positive cells in the molecular and granular layers with mild positive immune reaction (Figure 22a). However, group II (atherosclerotic) showed abundant large GFAP positive cells with strong positive immune reaction, mainly in the molecular layer and granular layer compared to the control (Figure 22b). GFAP immunostaining of astrocytes in group III(atherosclerotic co Q10) showed decreased positive staining, giving moderate positive immune reaction (Figure 22c) while GFAP immunostaining of astrocytes of group IV(atherosclerotic Silymarin) showed decreased positive staining, giving mild positive immune reaction (Figure 22d).

PCNA immunohistochemical staining of cerebellar cortices of control rats (group I) showed strong nuclear intensity of Purkinje cells and granule cells for PCNA immunostaining (Figure 23a). In addition, cerebellar cortices of Co Q10 and of Silymarin-treated rats showed the same appearance as control group. However, rats of atherosclerotic group (group II) showed negative nuclear reaction of Purkinje cells and mild positive nuclear immune reaction for PCNA immunostaining in granule cells compared with control group (group I) (Figure 23b). While, strong positive nuclear immune reaction of PCNA in Purkinje cells and granule cells was observed in the cerebellar cortices of both group III(atherosclerotic Co Q10 -treated group) and group IV (atherosclerotic Silymarin-treated group) (Figures 23c,d).

Immunohistochemically stained sections for Cox-2 of cerebellar cortices of rats of control group (group I) showed low cytoplasmic intensity of immune reaction for COX-2 of the molecular layer, Purkinje cells and the granule cells (Figure 24a).In atherosclerotic (group II), strong +ve highintensity COX-2 immune reaction was seen in granular layer, Purkinje cells and molecular layer (Figure 24b). Moderate intensity immune reaction of COX-2 in group III (atherosclerotic Co Q10 -treated group) was seen in all layers (Figure 24c). While, group IV (atherosclerotic Silymarin- treated group) showed mild -intensity immune reaction of Cox-2 in all layers (Figure 24d).

\section{Biochemical results}

There was a non-significance difference between subgroups of control animals. While the atherosclerotic induced group (group II) recorded a highly significant increase $(p<0.001)$ in serum level of both triglycerides, LDL-C and total cholesterol in comparison to control groups, while, level of HDL-C significantly decreased $(P<0.05)$ when compared with control groups,. However, in atherosclerotic
Co Q10 (group III) and atherosclerotic Silymarin treated rats (group IV), the serum level of triglycerides, LDL-C and total cholesterol showed a highly significant decrease $(p<0.001)$, while HDL-C level was increased significantly $(P<0.05)$ when compared with atherosclerotic animals (Table 2 ).

Atherosclerotic rats (group II) showed a highly significant reduction $(p<0.001)$ of all antioxidant markers; SOD, CAT and a highly significant increase in oxidative marker MDA when compared to control. However, atherosclerotic Co Q10 group (group III) and atherosclerotic Silymarin group (group VI),demonstrated a highly significant increase in CAT and SOD while, level of MDA showed a highly significant decrease compared to atherosclerotic (group II) (Table 3, Histogram 1).

\section{Morphometric results}

Data in (Table 4) showed that there was no significance difference between the control subgroups. The atherosclerotic rats (group II) exhibited a highly significant $(P<0.001)$ decrease of mean total number of Purkinje cells compared to control group. Rats of atherosclerotic Co Q10 (group III) showed significant increase $(P<0.05)$ of number of Purkinje cells with comparison with atherosclerotic (group IV). While rats of atherosclerotic Silymarin (group IV) exhibited a highly significant $(P<0.001)$ increase in Purkinje cells in comparison to atherosclerotic (group II) (Table 4, Histogram 2).

Data in (Table 5, Histogram 3) demonstrated that there was no significance difference between the control subgroups. The atherosclerotic rats (group II) exhibited a highly significant $(P<0.001)$ increase of intensity of GFAP immunereaction of cerebellar cortex, compared to control. While, on administration of coQ10 to atherosclerotic rats (group III), they exhibited a highly significant decrease of intensity of GFAP immunereaction in comparison with atherosclerotic group (group II). However, cerebellar cortex of rats of group IV(Atherosclerotic Silymarin treated) revealed highly significant decrease $(P<0.001)$ in intensity of GFAP immunereaction with comparison with the atherosclerotic group (group II).

In addition, (Table 5, Histogram 3) also showed that there was no significance difference between the control subgroups. The atherosclerotic rats (group II) exhibited highly significant increase $(P<0.001)$ of intensity of Cox2 immunereaction in cerebellar cortex, when compared with the control group. However, rats of the atherosclerotic Co Q10 treated (group III) and atherosclerotic Silymarin treated (group IV) showed significant decrease $(P<0.05)$ of intensity of Cox-2 immunereaction in comparison with the atherosclerotic rats (group II). 


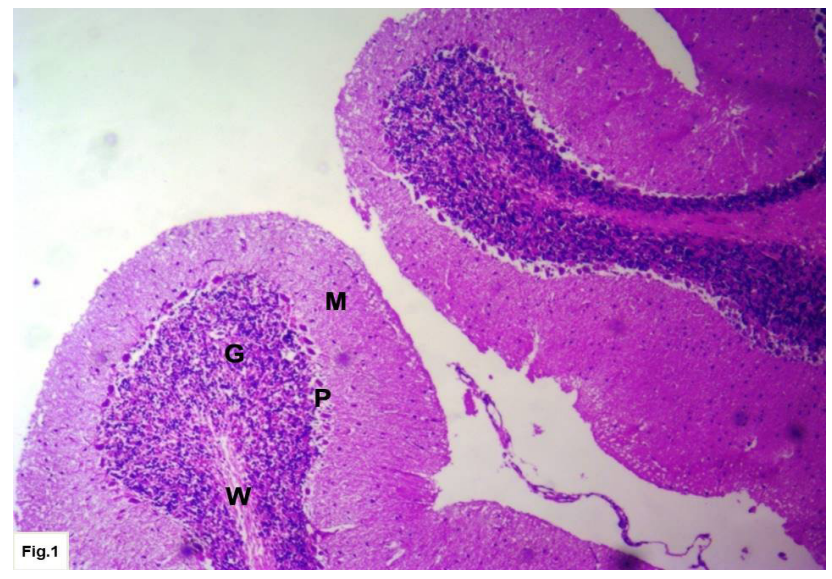

Fig. 1: A photomicrograph of cerebellar section of control rat (group I) showing cerebellum folium formed of outer gray matter, consists of molecular (M), Purkinje cell layer (P), and granular layer $(\mathrm{G})$ and the inner white matter (W). (H\&E X100)

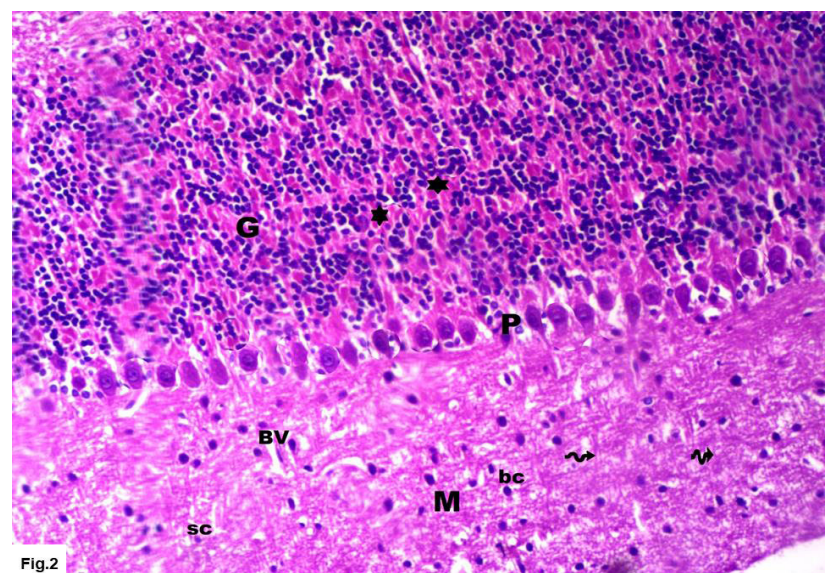

Fig. 2: A photomicrograph of section of cerebellar cortex of control rat (group I) showing outer molecular layer (M), containing fibers (zigzag arrow), basket cells (bc) and stellate cells (sc).The middle Purkinje cell layer $(\mathrm{P})$, arranged in single row. granular layer $(\mathrm{G})$ formed of aggregation of tightly packed small cells with dark spherical nuclei among pale areas, called cerebellar islands (stars). Note presence of small blood capillary (BV) in the molecular layer. (H\& E X200)

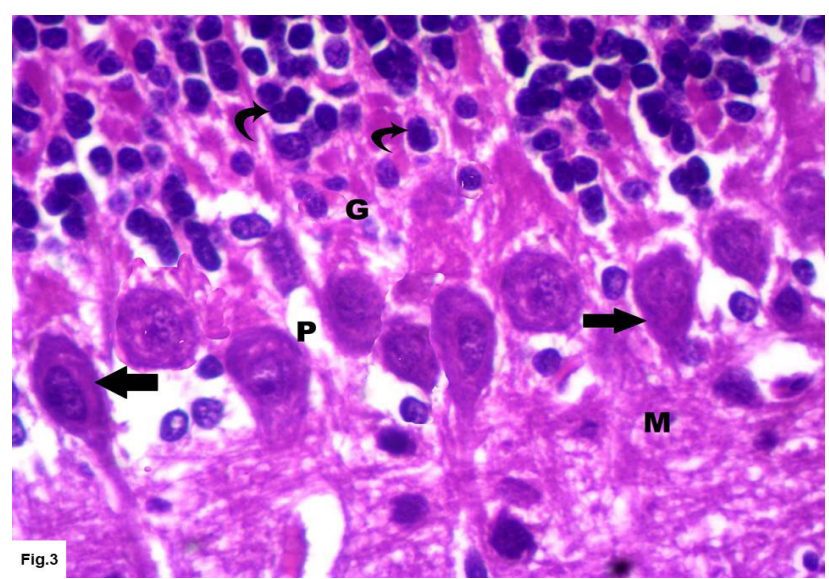

Fig. 3: A photomicrograph of section of cerebellar cortex of control rat showing part of molecular layer (M),Purkinje(P)cell layer consists of large pyriform cells, containing large rounded vesicular nuclei with prominent nucleoli and pale acidophilic cytoplasm with scattered basophilic Nissl granules (arrows). The granular layer $(G)$, composed of well-defined clumps of small rounded cells with deeply stained nuclei and scanty cytoplasm (curved arrows).

(H\&E X400)

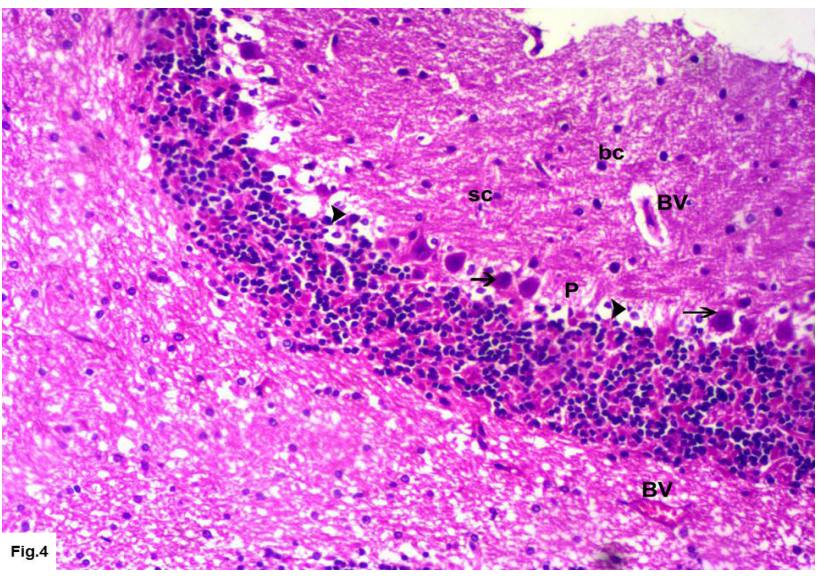

Fig. 4: A photomicrograph of section of cerebellar cortex from atherosclerotic rat (group II) showing disruption of Purkinje cell layer (P). Irregular -shaped Purkinje cells with deep homogenous cytoplasm and absence of Nissl granules with darkly stained pyknotic nuclei (arrows) are seen. Other Purkinje cells are lost, leaving empty spaces, surrounded by neuroglia cells (arrowheads). Frequent stellate cells (sc) and basket cells (bc) also observed. Notice congested blood vessel (BV). (H\& E X200)

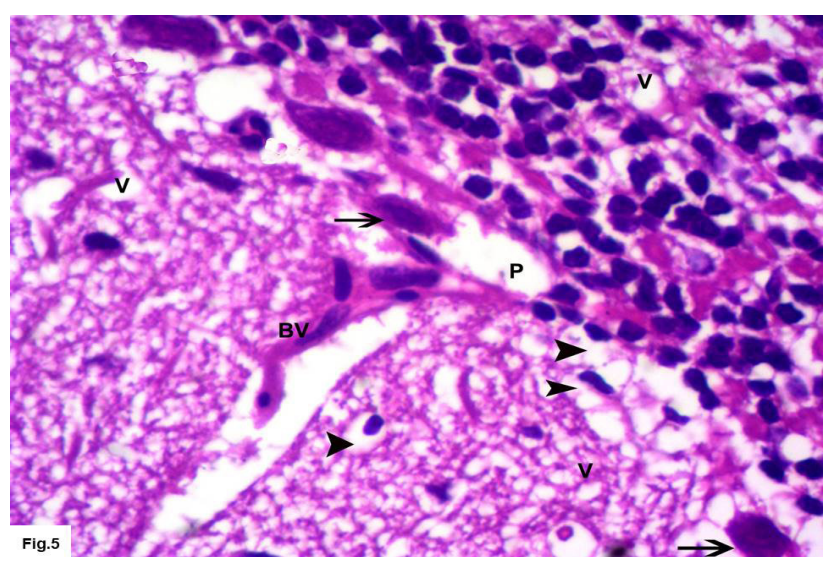

Fig. 5: A photomicrograph of section of cerebellar cortex from atherosclerotic rat showing Purkinje cells having darkly stained nuclei and cytoplasm (arrows) in Purkinje cell layer (P). Perineural spaces (arrowheads) are present around Purkinje, stellate cells and basket ncells Vacuolations (V) of molecular and granular layers are also present Notice congested dilated blood vessel (BV). (H\& E X400)

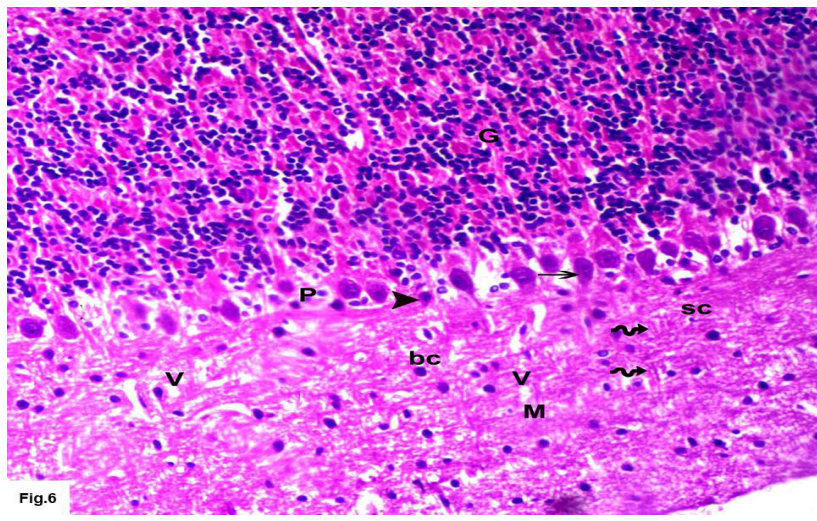

Fig. 6: A photomicrograph of section of cerebellar cortex of atherosclerotic rat treated with Coenzyme Q10 (group III) showing most of Purkinje cells (arrows) in the Purkinje cell layer (P),having appearance similar to control group. However, some Purkinje cells are irregula and darkly stained (arrowheads). Molecular layer (M) consists of fibers (zigzag arrows), small basket (bC) and stellate (sc) cells. Granular layer (G) is apparently normal. Note slight vacuolations (V) of the molecular layer. (H\& E X200) 


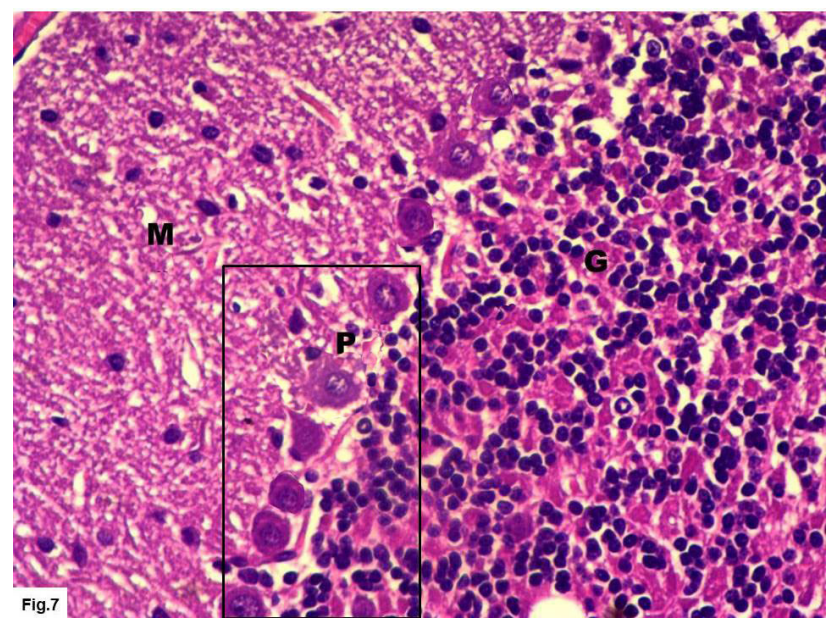

Fig. 7: A photomicrograph of section of cerebellar cortex of atherosclerotic Silymarin treated rat (group IV) showing Purkinje cell layer (P),granular layer(G) and molecular layer (M) having an appearance similar to control group. (H\& E X200)

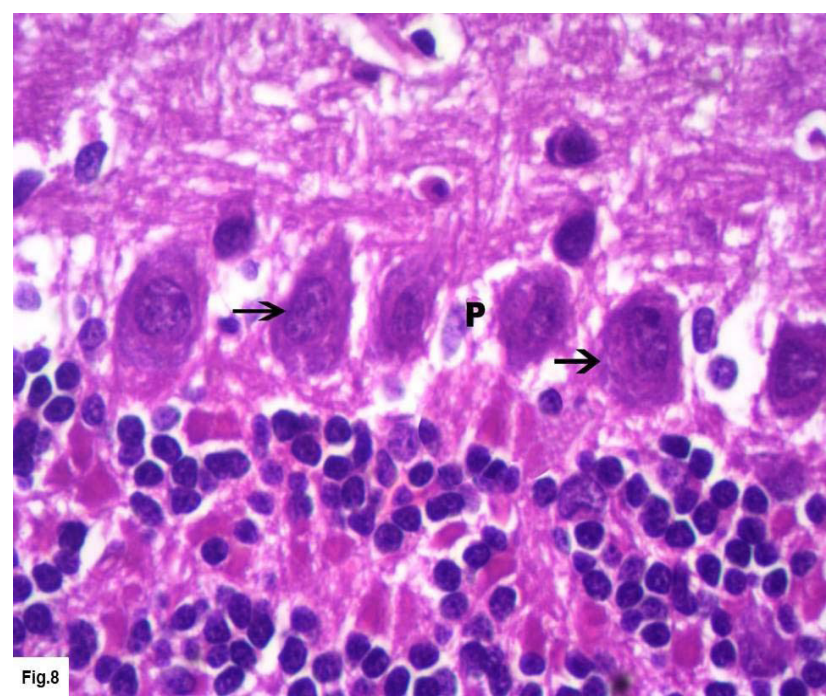

Fig. 8: Higher magnification of the previous picture showing normal shape and size of Purkinje cells (arrows) in Purkinje cell layer (P). (H\& E X400)

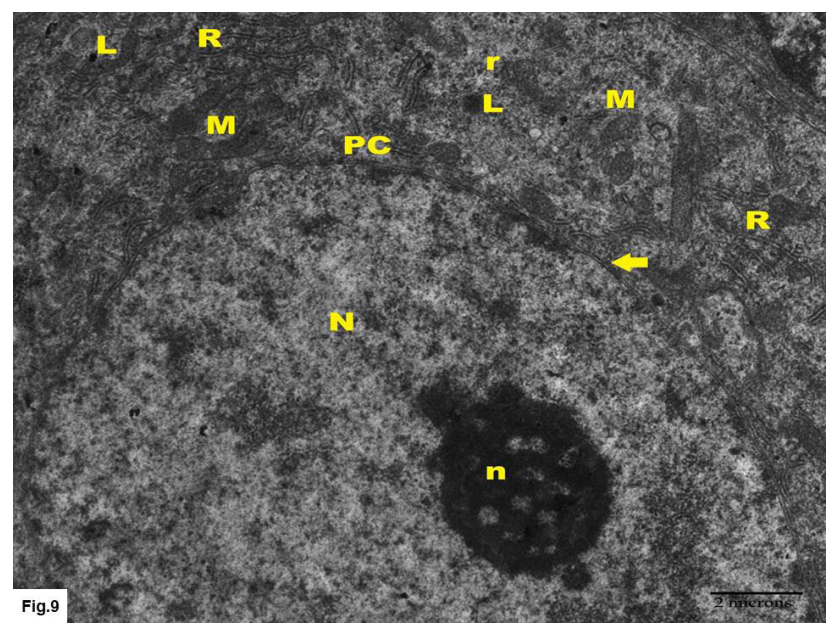

Fig. 9: Electron micrograph of section of control cerebellar cortex(group I) showing Purkinje cell (PC) containing euchromatic nucleus (N), prominent nucleolus (n) with well defined nuclear membrane(arrow). Its cytoplasm has cisternae of rough endoplasmic reticulum (R), mitochondria (M), lysosomes (L)and free ribosomes (r) (TEM X15000)

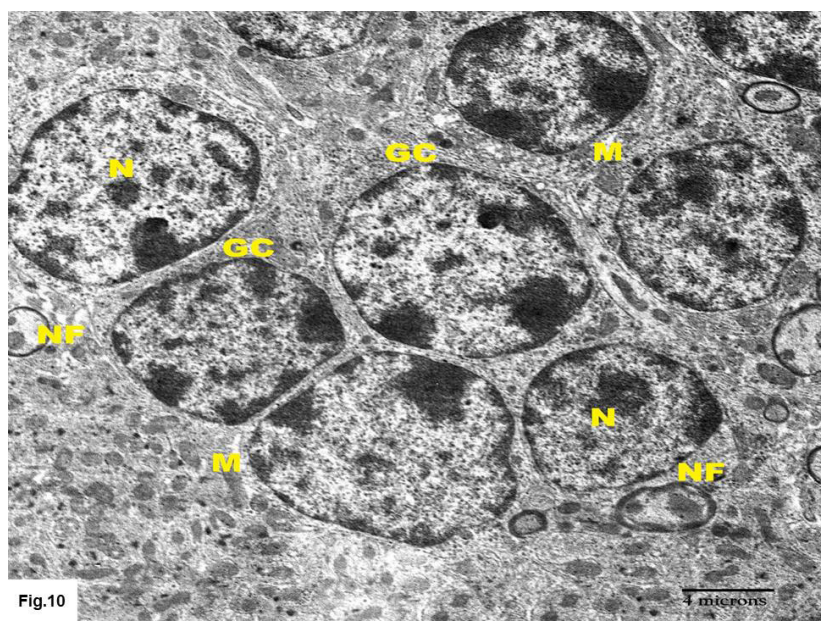

Fig. 10: Electron micrograph of section of control cerebellar cortex(group I) showing granular cells (GC) having rounded nuclei containing peripheral clumps of heterochromatin $(\mathrm{N})$, enveloped with thin rim of cytoplasm, containing free ribosomes (r) and mitochondria (M) Mylinated nerve fibers(NF) are also present. (TEM x 5000)

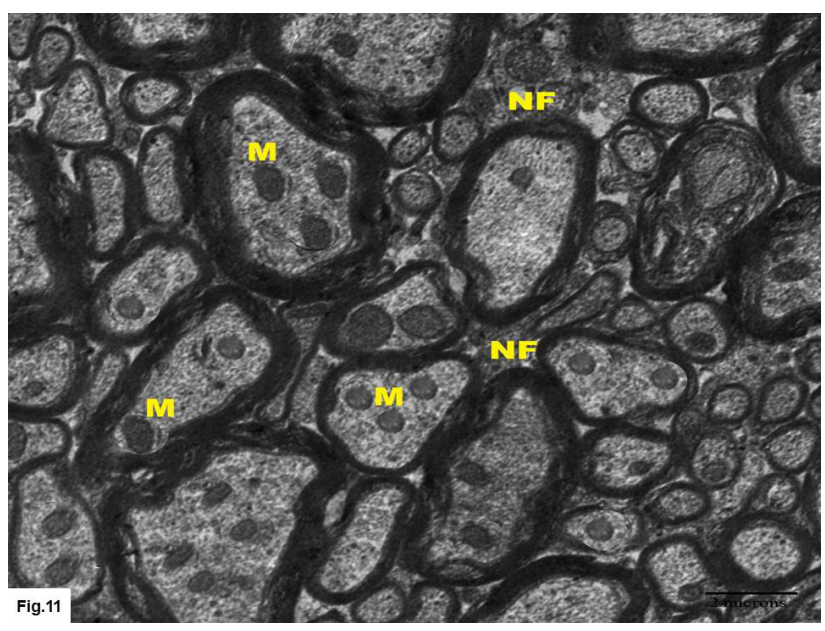

Fig. 11: Electron micrograph of section of cerebellar cortex of control rat (group I) showing the molecular layer, containing multiple mylinated nerve fibers (NF), filled with mitochondria (M). (TEM x 15000)

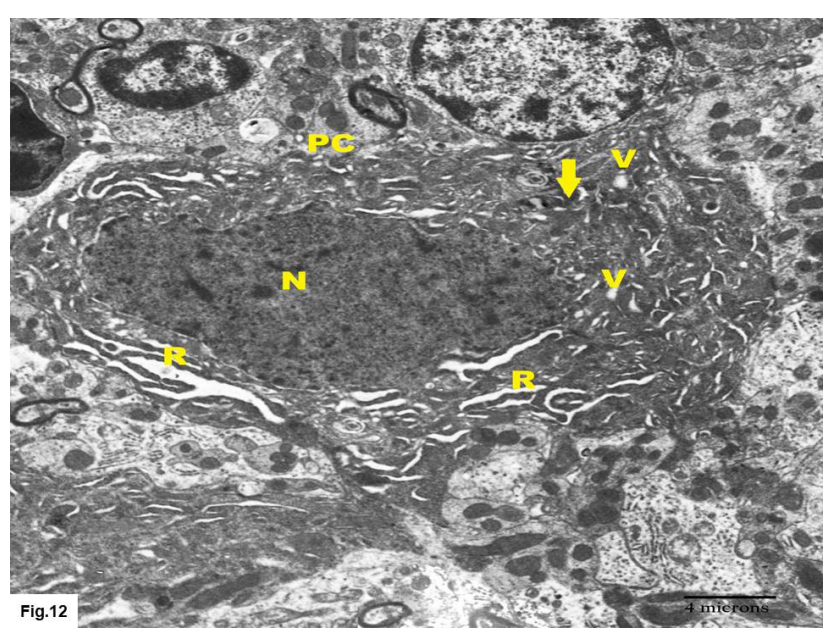

Fig. 12: Electron micrograph of cerebellar cortex of atherosclerotic rat (group II) showing shrunken Purkinje cell (PC) having flat indented nucleus $(\mathrm{N})$ with dilated cisternae of rough endoplasmic reticulum $(\mathrm{R})$ and cytoplasmic vacuoles $(\mathrm{V})$. Note the presence of many electron dense vesicles (arrow). (TEM x 5000) 


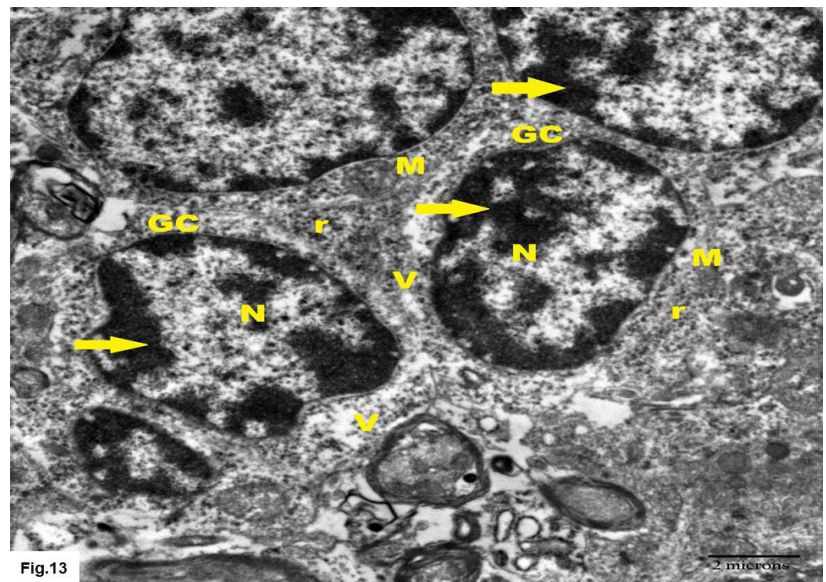

Fig. 13: Electron micrograph of atherosclerotic cerebellar cortex (group II) showing granular cells (GC) having higher condensation of nuclear chromatin (arrows) in nuclei (N). Cytoplasm contains mitochondria with destroyed cristae(M), free ribosomes(r) and areas of vacuolation (v). Notice presence of small pyknotic nucleus of granule cell (arrow head) and disruption of myelinated nerve fibers (NF). (TEM x 15000)

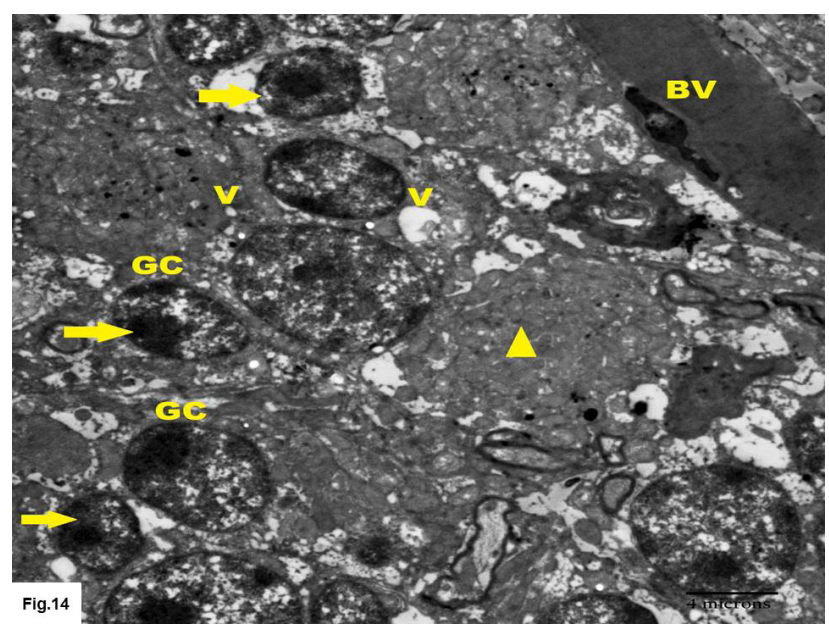

Fig. 14: Electron micrograph of atherosclerotic cerebellar cortex (group II) showing granule cells (GC), some of them containing small pyknotic nuclei (arrows), others are apoptotic (arrow head). Note the presence of vacuolated cytoplasm (V) and congested blood vessel (BV). (TEM x 5000

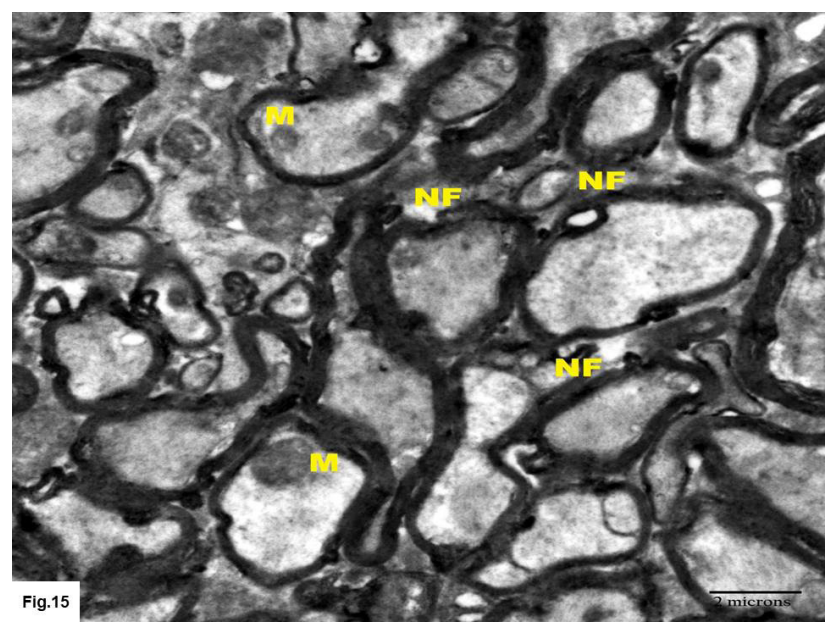

Fig. 15: Electron micrograph of section of cerebellar cortex of atherosclerotic rat (group II) showing molecular layer with disruption and dissociation of myelinated nerve fibers (NF). Degenerated mitochondria (M) are also seen in some fibers. (TEM x 15000)

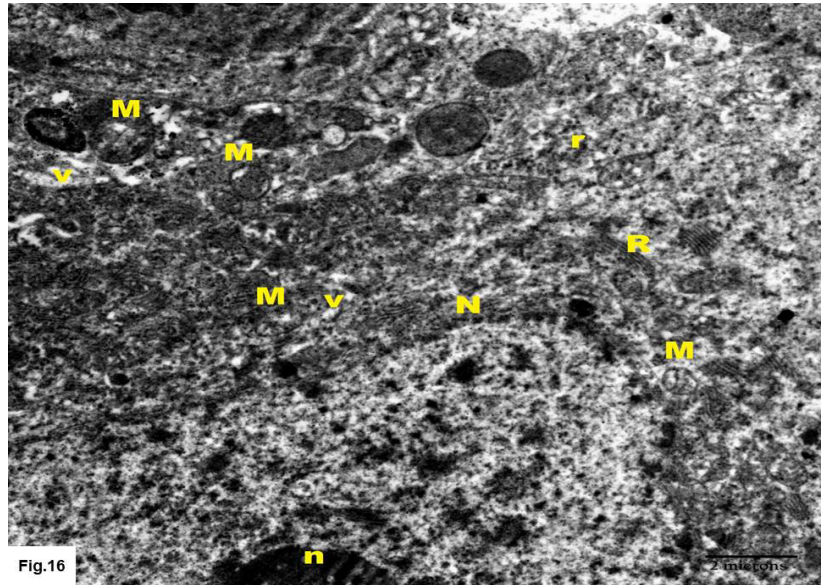

Fig. 16: Electron micrograph of cerebellar cortex of atherosclerotic $\mathrm{Co}$ enzyme Q10 treated rat (group III) showing Purkinje cell containing euchromatic nucleus $(\mathrm{N})$, apparent nucleolus (n). It contains cisternae of rough endoplasmic reticulum $(\mathrm{R})$ and numerous small electron dense ribosomes (r). Degenerated mitochondria (M) and some vacuoles (V) are still present. (TEM x 15000)

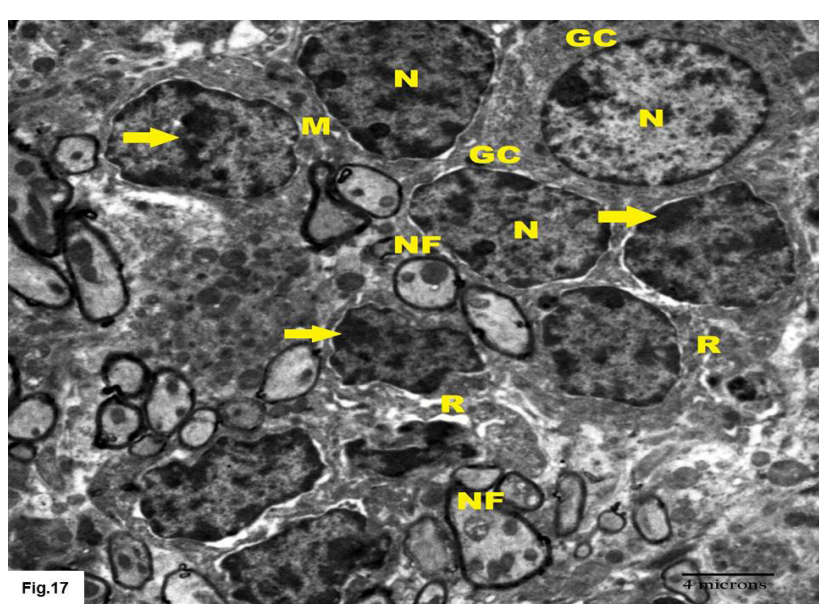

Fig. 17: Electron micrograph of cerebellar cortex of atherosclerotic and Co enzyme Q10 (group III) showing nearly normal granular cells (GC), having rounded nuclei $(\mathrm{N})$ and surrounded by rim of cytoplasm. Other cells, exhibited increased condensation of their nuclear chromatin (arrows) and dilated cisternae of rough endoplasmic reticulum(R). Mylinated nerve fibers (NF) are more or less normal. (TEM x5000)

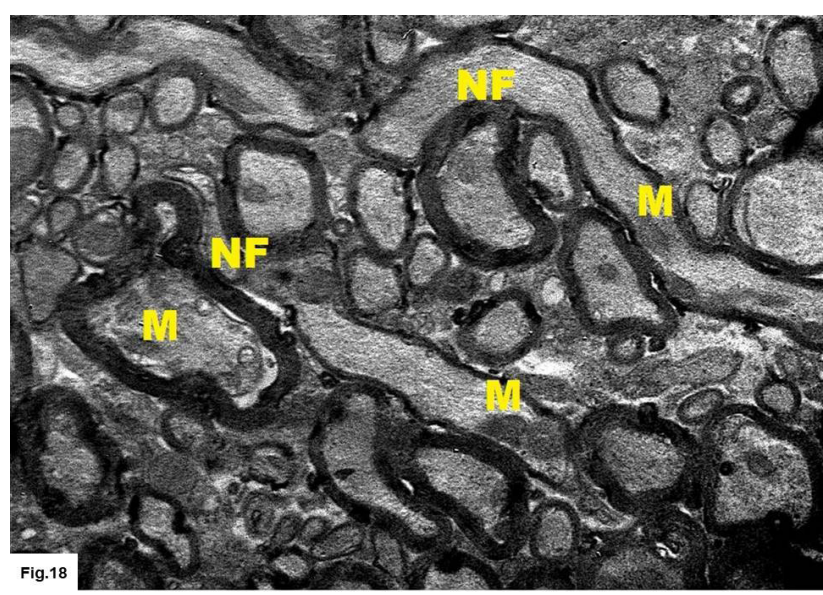

Fig. 18: Electron micrograph of cerebellar cortex of atherosclerotic rat and Co enzyme Q10 (group III) showing the molecular layer, containing nearly intact normal myelinated nerve fibers (NF). Few myelinated fibers with slight distortion of its myelin sheath are present (arrows). (TEM x 15000) 


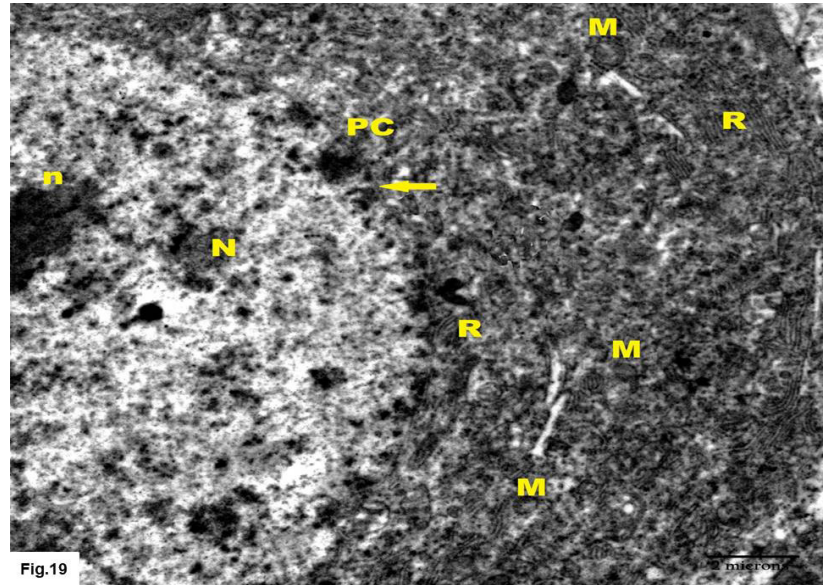

Fig. 19: Electron micrograph of cerebellar cortex of atherosclerotic with Silymarin (group IV) showing Purkinje cell (PC) having large euchromatic nucleus $(\mathrm{N})$, nucleolus (n) with well defined nuclear membrane (arrow). It has well-defined rough endoplasmic reticulum (R) and electron dense mitochondria (M). (TEM x 15000)

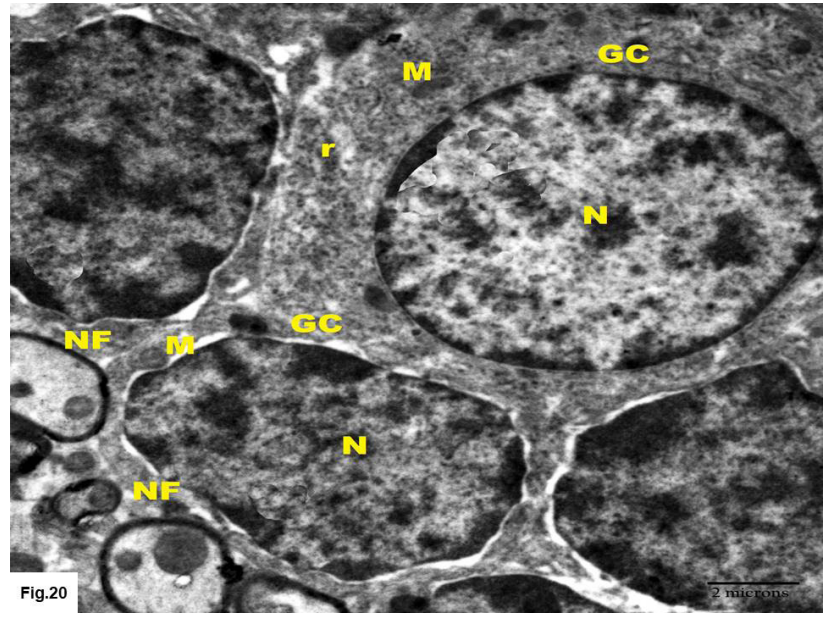

Fig. 20: Electron micrograph of cerebellar cortex of atherosclerotic treated with Silymarin (group IV) showing granule cells (GC)having rounded or oval nuclei $(\mathrm{N})$ with peripheral clumps of heterochromatin and enveloped with shell of cytoplasm, having mitochondria (M), free ribosomes (r). Mylinated nerve fibers (NF) are more or less like control group. (TEM x 15000)

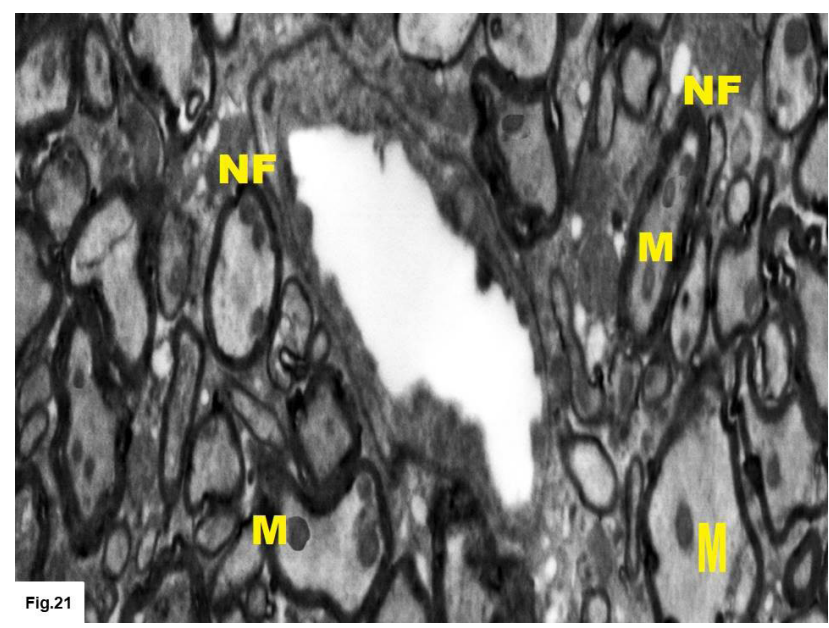

Fig. 21: Electron micrograph of cerebellar cortex of atherosclerotic rat and Silymarin (group IV) showing molecular layer having nearly normal mylinated nerve fibers (NF). (TEM x 5000)

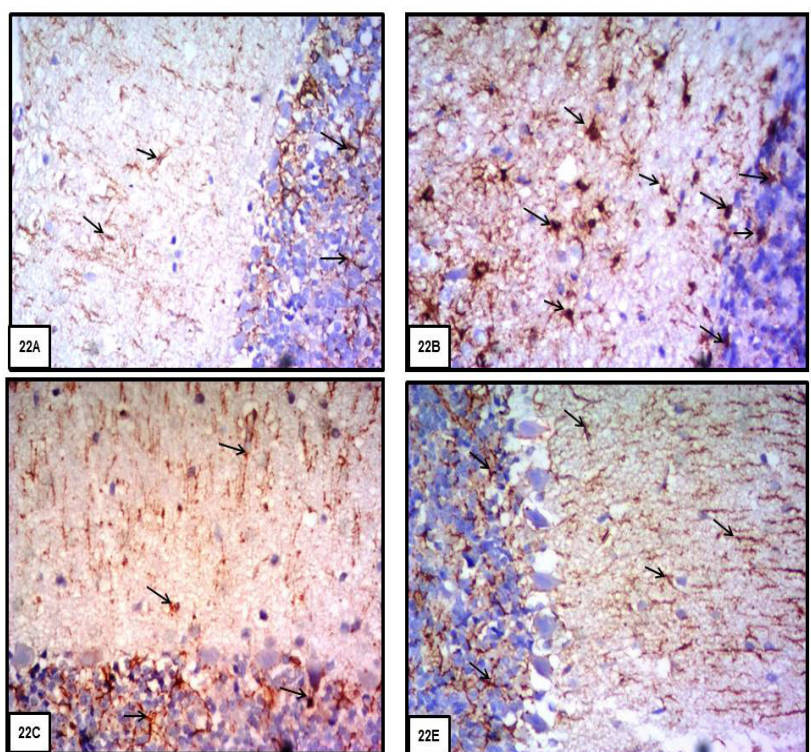

Fig. 22: GFAP immunohistochemical staining of rat cerebellar cortices showing:

(a) Control group (group I) showing scattered GFAP positive cells in granular and molecular layers with mild positive immune reaction (arrows).

(b) Group II (atherosclerotic) showing abundant large GFAP positive cells with strong positive immune reaction, mainly in the molecular layer and granular layer (arrows)

(c) GFAP immunostaining of astrocytes in group III(atherosclerotic treated-co enzyme 10) showing decreased positive staining, giving mild positive immune reaction (arrows).

(d) Group IV showing decreased positive staining, giving mild positive immune reaction (arrows). (GFAP x200 immunostaining)
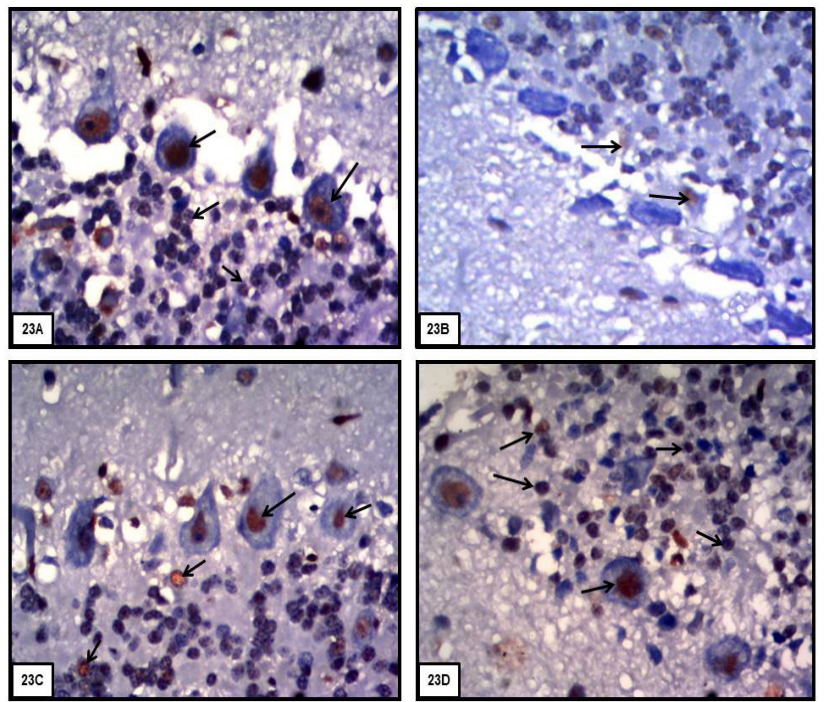

Fig. 23: PCNA immunohistochemical staining of rat cerebellar cortices showing:

(a) Control group (group I) showing strong nuclear intensity of Purkinje cells and granule cells for PCNA immunostaining(arrows)

(b) Group II (atherosclerotic) showing negative nuclear immune reaction for PCNA immunostaining in Purkinje cells and mild positive immune reaction in granule cells (arrows)

(c) Group III (atherosclerotic coQ10 -treated group) showing strong nuclear intensity for PCNA in Purkinje cells and granule cells (arrows).

(d) Group IV (atherosclerotic Silymarin- treated group) showed strong positive nuclear immune expression of PCNA of Purkinje cells, granule cells (arrows). (PCNA x 400 immunostaining) 

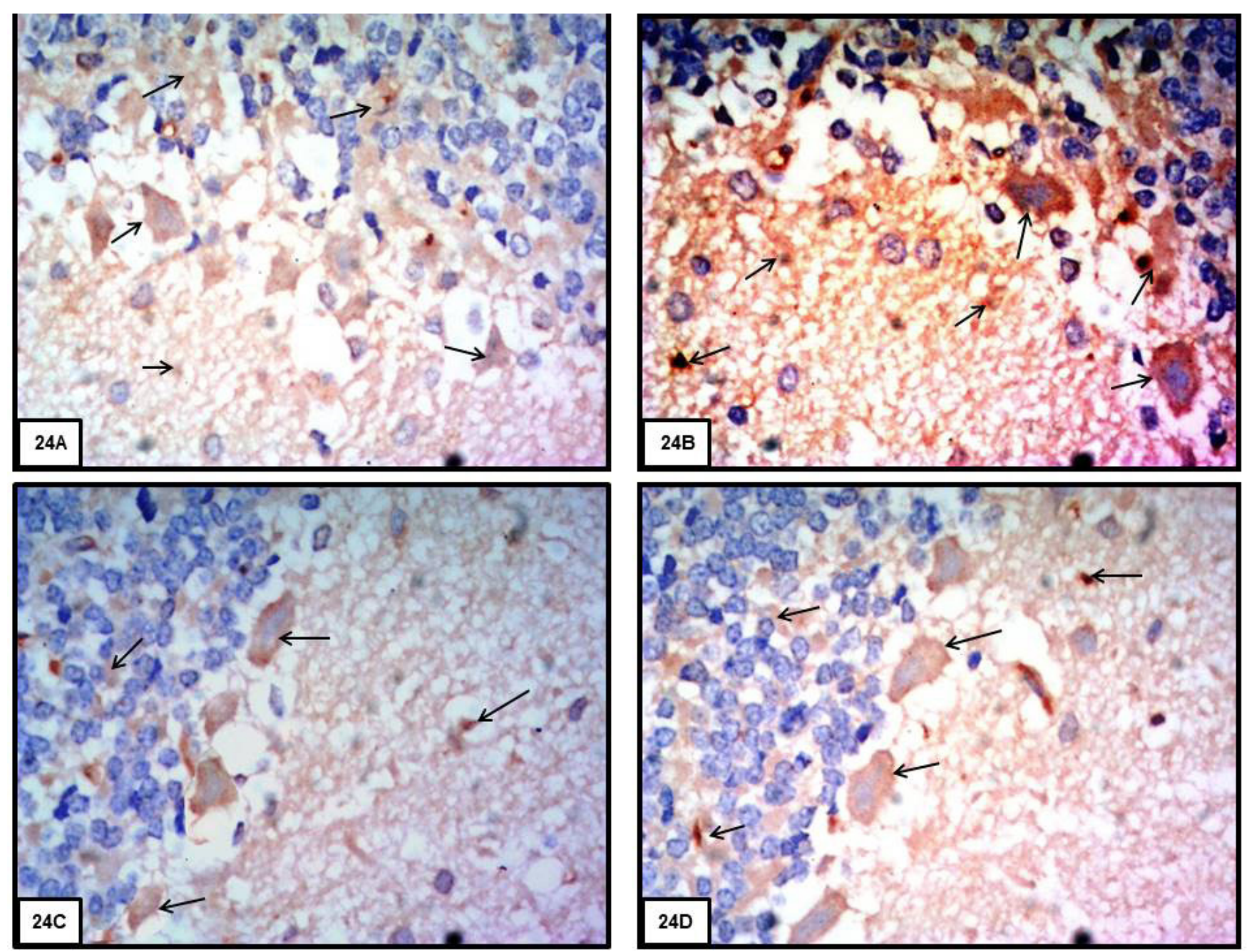

Fig. 24: Cox-2 immunohistochemical staining of rat cerebellar cortices showing:

(a) Control group (group I) showing low cytoplasmic intensity of COX-2 immune reaction in molecular layer, granular layer and Purkinje cells (arrows).

(b) Group II (atherosclerotic) showing a strong positive high-intensityCOX-2 immune reaction in the molecular layer, Purkinje cells, and the granular layer(arrows).

(c) Group III (atherosclerotic coQ10 -treated group) showing moderate-intensity immune reaction of COX-2 in all layers (arrows).

(d) Group IV(atherosclerotic Silymarin- treated group) showed mild -intensity immune reaction of Cox-2 in all layers (arrows). (Cox-2 x 400 immunostaining)

Table 1: Mean weight in grams in different groups

\begin{tabular}{|c|c|c|c|c|c|c|}
\hline Mean weight & $\begin{array}{c}\text { Control } \\
\text { (subgroup IA) } \\
\mathrm{x}^{-} \pm \mathrm{SD}\end{array}$ & $\begin{array}{c}\text { Co Q10 } \\
\text { (subgroupIB) } \\
\mathrm{x}^{-} \pm \mathrm{SD}\end{array}$ & $\begin{array}{c}\text { Silymarin } \\
\text { (subgroup IC) } \\
\mathrm{x}^{-} \pm \mathrm{SD}\end{array}$ & $\begin{array}{c}\text { Group II } \\
\text { (atherosclerotic) } \\
\text { induced } \\
\mathrm{x}^{-} \pm \mathrm{SD}\end{array}$ & $\begin{array}{c}\text { GroupIII } \\
\text { (atherosclerotic } \\
\text { CoQ10) } \\
\mathrm{x}^{-} \pm \mathrm{SD}\end{array}$ & $\begin{array}{c}\text { Group IV } \\
\text { (atherosclerotic } \\
\text { Silymarin) } \\
\mathrm{x}^{-} \pm \mathrm{SD}\end{array}$ \\
\hline Initial weight & $195.4 \pm 6.813$ & $201 \pm 3.741$ & $200 \pm 21.382$ & $203.7 \pm 10.21$ & $198.7 \pm 5.71$ & $196.8 \pm 5.91$ \\
\hline Weight at end of study & $370 \pm 7.648$ & $380 \pm 6.795$ & $377 \pm 8.080$ & $520 \pm 8.40^{* *}$ & $415 \pm 10.211^{\star}$ & $398.12 \pm 3.974 * *$ \\
\hline
\end{tabular}

$\mathrm{x}^{-}=$the mean value. $\mathrm{SD}=$ the standard deviation.

- Significant $(P<0.05)$ from atherosclerotic group

(*) Significant when compared with control group $(\mathrm{P}<0.05)$

$\bullet$ Highly significant with atherosclerotic group $(p<0.001)$

** Highly significant $(p<0.001)$ with control group 
Table 2: Mean levels of serum triglycerides, HDL-C, cholesterol, , LDL-C of the different studied groups expressed as mg/dl.

\begin{tabular}{lccc}
\hline \multicolumn{1}{c}{ Group } & $\begin{array}{c}\text { Triglycerides } \\
\mathrm{x}^{-} \pm \mathrm{SD}\end{array}$ & $\begin{array}{c}\text { Total cholesterol } \\
\mathrm{x}^{-} \pm \mathrm{SD}\end{array}$ & $\begin{array}{c}\text { HDL-C } \\
\mathrm{x}^{-} \pm \mathrm{SD}\end{array}$ \\
\hline Control (Subgroup IA) & $95.89 \pm 6.69$ & $105.93 \pm 10.66$ & $43.62 \pm 3.89$ \\
Co Q10 treated (Subgroup IB) & $98.92 \pm 4.34$ & $108.24 \pm 5.36$ & $39.01 \pm 3.78$ \\
Silymarin treated (Subgroup IC) & $94.67 \pm 4.63$ & $100.1 \pm 4.29$ & $40.03 \pm 4.12$ \\
Atherosclerotic induced (groupII) & $159.4 \pm 6.21^{* *}$ & $208.30 \pm 30.78^{* *}$ & $23.36 \pm 2.81^{*}$ \\
Atherosclerotic Co Q10 (group III) & $104.92 \pm 4.34^{* *}$ & $112.24 \pm 5.36^{* *}$ & $31.35 \pm 2.92$ \\
Atherosclerotic Silymarin (group IV) & $100.52 \pm 3.34^{* *}$ & $121.33 \pm 2.76^{* *}$ & $40.04 \pm 3.72$ \\
\hline
\end{tabular}

$\mathrm{x}^{-}=$the mean value. $\mathrm{SD}=$ the standard deviation.

$\checkmark$ Significant $(P<0.05)$ from atherosclerotic group

$\leftrightarrow$ Highly significant with atherosclerotic group $(p<0.001)$.

(*) Significant when compared with control group $(\mathrm{P}<0.05)$

** Highly significant $(p<0.001)$ with control group

Table 3: Mean values of tissue MDA, SOD and CAT in the different studied groups

\begin{tabular}{lccc}
\hline \multicolumn{1}{c}{ Group } & MDA(nmol/mgprotein) & SOD(u/mg protein) & CAT(U/mg protein) \\
& $x^{-} \pm$SD & $12.5 \pm 0.99$ & $23.12 \pm 1.71$ \\
\hline Control (Subgroup IA) & $2.2 \pm 0.7$ & $12.77 \pm 0.87$ & $24.31 \pm 1.82$ \\
Co Q10 treated (Subgroup IB) & $2.34 \pm 0.5$ & $13.0 \pm 0.96$ & $25.0 \pm 2.03$ \\
Silymarin treated (Subgroup IC) & $1.99 \pm 0.8$ & $6.3 \pm 0.76^{* *}$ & $12.3 \pm 0.8^{* *}$ \\
Atherosclerotic induced (groupII) & $14.9 \pm 1.93^{* *}$ & $11.0 \pm 0.12^{* *}$ & $21.07 \pm 0.93^{* *}$ \\
Atherosclerotic Co Q10 (group III) & $5.44 \pm 1.2^{* *}$ & $13.0 \pm 0.96^{* *}$ & $22.76 \pm 1.2^{* *}$ \\
Atherosclerotic Silymarin (group IV) & $4.21 \pm 0.81^{* *}$ & & \\
\hline
\end{tabular}

$\mathrm{x}^{-}=$the mean value. $\mathrm{SD}=$ the standard deviation.

\Significant $(P<0.05)$ from atherosclerotic group

$\leftrightarrow$ Highly significant with atherosclerotic group $(p<0.001)$

(*) Significant when compared with control group $(\mathrm{P}<0.05)$

** Highly significant $(p<0.001)$ with control group

Table 4: Mean of Purkinje cell count in the different studied groups

\begin{tabular}{cc}
\hline Group & Purkinje cell count \\
$\mathrm{x}^{-} \pm \mathrm{SD}^{2}$ & $15.078 \pm 1.245$ \\
\hline Control (Subgroup IA) & $13.376 \pm 1.250$ \\
Co Q10 treated (Subgroup IB) & $14.03 \pm 1.071$ \\
Silymarin treated (Subgroup IC) & $4.38 \pm 0.988^{* *}$ \\
Atherosclerotic (group II) & $9.692 \pm 0.862^{*}$ \\
Atherosclerotic Co Q10 (group III) & $12.769 \pm 0.719 * *$ \\
\hline Atherosclerotic Silymarin (group IV)
\end{tabular}

$\mathrm{x}^{-}=$the mean value. $\mathrm{SD}=$ the standard deviation.

$\checkmark$ Significant $(P<0.05)$ from atherosclerotic group

(*) Significant when compared with control group $(\mathrm{P}<0.05)$

$\downarrow$ Highly significant with atherosclerotic group $(p<0.001)$

** Highly significant $(p<0.001)$ with control group

Table 5: Means and standard deviations (SD) of the intensity of GFAP immune reaction \& the intensity of Cox-2 immune reaction of various experimental groups

\begin{tabular}{lcc}
\hline \multicolumn{1}{c}{ Group } & $\begin{array}{c}\text { Intensity of GFAP immune reaction } \\
\mathrm{x}^{-} \pm \mathrm{SD}\end{array}$ & $\begin{array}{c}\text { Intensity of Cox-2 immune reaction } \\
\mathrm{x}^{-} \pm \mathrm{SD}\end{array}$ \\
\hline Control (Subgroup IA) & $40.102 \pm 2.125$ & $4.086 \pm 1.022$ \\
Co Q10 treated (Subgroup IB) & $43.812 \pm 3.832$ & $3.981 \pm 1.327$ \\
Silymarin treated (Subgroup IC) & $38.28 \pm 2.832$ & $4.076 \pm 1.356$ \\
Atherosclerotic induced (groupII) & $69.365 \pm 1.869 * *$ & $11.98 \pm 0.827 * *$ \\
Atherosclerotic Co Q10 (group III) & $49.542 \pm 3.021 \bullet$ & $7.591 \pm 1.025 \downarrow$ \\
Atherosclerotic Silymarin (group IV) & $42.82 \pm 3.471 \bullet$ & $6.0431 \pm 2.091 \star$ \\
\hline
\end{tabular}

$\mathrm{x}^{-}=$the mean value. $\mathrm{SD}=$ the standard deviation.

$\downarrow$ Significant $(P<0.05)$ from atherosclerotic group

(*) Significant when compared with control group $(\mathrm{P}<0.05)$

$\downarrow$ Highly significant with atherosclerotic group $(p<0.001)$

** Highly significant $(p<0.001)$ with control group 


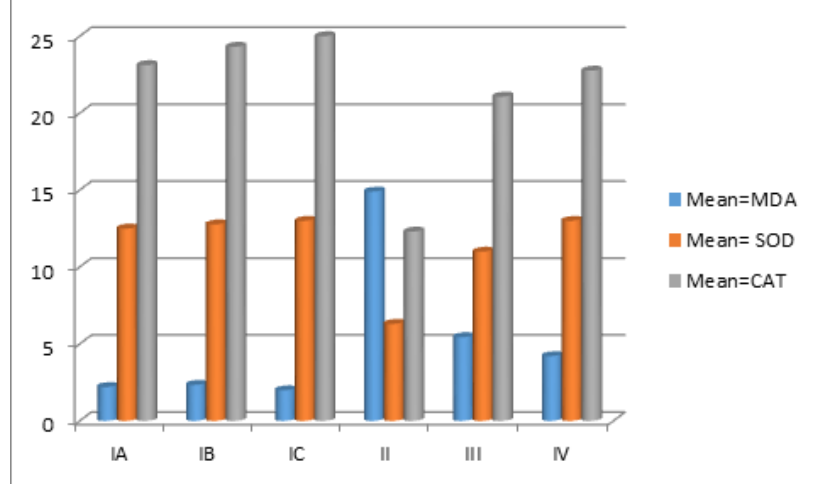

Histogram 1: Mean values in tissue MDA, SOD and CAT in the different studied groups

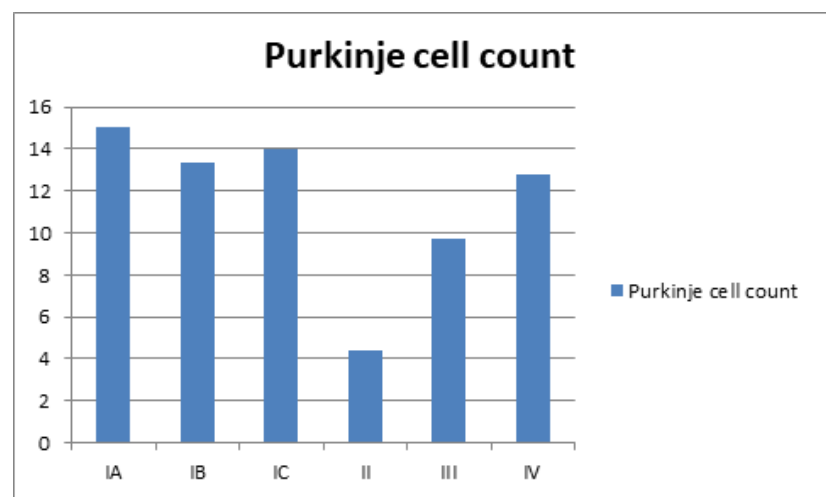

Histogram 2: Mean of Purkinje cell count in the different studied groups

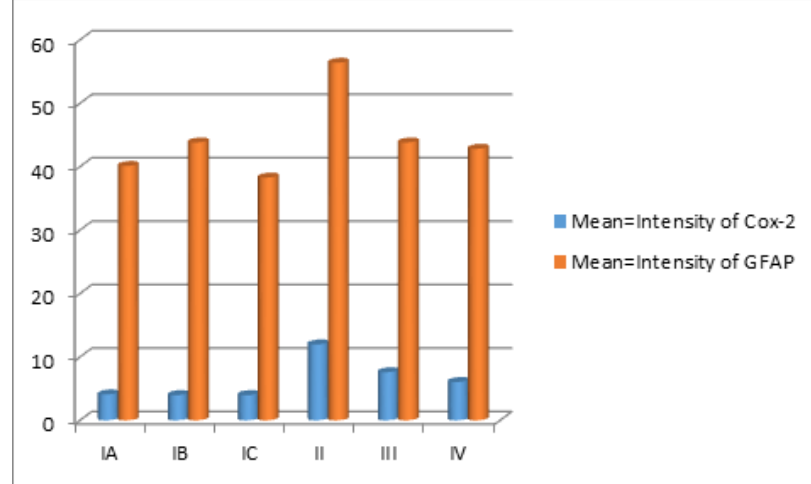

Histogram 3: Morphometric analysis of optical density of Cox-2 and GFAP performed on rat cerebellar cortex

\section{DISCUSSION}

Atherosclerosis (AS) is a complex arterial wall disease induced by development of plaques that contribute to progressive arterial occlusion and ischemia. In this study, three months of cerebellar atherosclerosis and ischemia were effectively caused by daily intake of hypercholesterolemic diet, proven by measured elevated levels of triglycerides and total plasma cholesterol in rats. Dietary cholesterol induces elevated levels of cholesterol in the blood, leading to lesions in the arterial wall ${ }^{[30]}$. The International Society for Atherosclerosis recommends decreasing dietary cholesterol as a strategy for lowering low-density lipoprotein cholesterol (LDL-C). It was reported that dietary cholesterol increases cardiovascular diseases (CVDs) risk ${ }^{[31]}$. A variety of experiments in rats fed with high cholesterol diet have observed a rise in plasma atherogenic lipids as plasma triglycerides and total cholesterol levels ${ }^{[32]}$. The current results showed that body weight increased significantly in the atherosclerotic group compared with the normal group. Previous researches have shown that dietary factors, particularly the consumption of a high fat diet (HFD) is considered a risk factor for development of obesity $^{[33]}$. In addition ${ }^{[34]}$, explained that consumption of hypercholesterolemic diet facilitates the development of a positive energy balance leading to an increase in visceral fat deposition, abdominal obesity and body weight gain. Moreover, ${ }^{[32]}$ found that high cholesterol feeding is accompanied by molecular adaptations that favor fat storage in muscle rather than oxidation that in turn cause obesity.

The cerebellar cortex of atherosclerotic animals displayed robust structural lesions in the cell layer of Purkinje, which are consistent with Abd El-Samad's findings ${ }^{[35]}$. Such changes in Purkinje cells revealed pathological love of the cerebellar cortex's chief cells, which are the only cells in the cerebellum that supply information to other parts of the brain ${ }^{[36]}$. Atherosclerotic rats showed Purkinje cell layer disruption with shrinking and loss of some of Purkinje cells leaving empty spaces around them. It had a smooth indented nucleus, and its cytoplasm comprises dilated cisterns of rough endoplasmic reticulum, vacuoles and several thick vesicles with electrons. This was consistent with ${ }^{[37]}$ which stated that cerebellar cells grown with cholesterol in cell culture induced neurodegeneration as indicated by altered morphology, reduced synaptic connections, and cell shrinkage compared with normal cells. Throughout this research, perineuronal spaces are found around Purkinje cells, basket and stellate cells. A previous work ${ }^{[38]}$ reported presence of such spaces.

The multiple electron dense bodies may be degenerated mitochondria, the product of auto-phagocytosis accompanied by lysosomal processing. This is considered a major degrading Mitochondria pathway ${ }^{[39]}$. In several neurodegenerative diseases mostly associated with oxidative damage ${ }^{[40]}$, mitochondrial alterations and dysfunctions were identified. There was also a significant decrease in Purkinje cells number which is coincided with other studies who found that the Purkinje cell number and density is decreased in neurodegenerative diseases as $\mathrm{AD}^{[28]}$.

Some granule cells having pyknotic nuclei, damaged mitochondria and vacuolated cytoplasm appeared in this sample, as well as other apoptotic granular cells. Excessive cholesterol results in apoptosis, and death of cells ${ }^{[37]}$. Moreover ${ }^{[41]}$ demonstrated that apoptosis was observed in multiple neurodegenerative diseases. These changes may be due to ischemia and cerebellar artery atherosclerosis as a result of a high intake of cholesterol. The degenerative changes of granule cells may be secondary to those of Purkinje cells ${ }^{[42]}$ stated that affected Purkinje cells had no normal contact with granular cells, resulting in loss of 
normal synchronism between the two types of cells, thus minimizing their regulatory function. In the present findings, the observed condensation of nuclear chromatin agrees with reports from other investigators who reported that dying neurons may undergo chromatin condensation and dissolution $^{[17]}$.

Some researchers have described vacuolation observed in Purkinje and granular cells as a result of significant disruptions in lipid inclusions ${ }^{[43]}$. Other researchers indicated that vacuolation may be caused by cell injury, resulting in increased development of reactive oxygen species (ROS) that likely invaded the membranes and altered their permeability ${ }^{[4]}$. Other studies have shown that lipid peroxidation considered autocatalytic process contributes to cellular membranes oxidative destruction which in turn contributes to development of toxic free radicals and cell death. Malondialdehyde (MDA) was the most important of those free radicals ${ }^{[45]}$

Myelin defects considered a cause for reduced nerve impulse transmission and brain disorders found in cerebellar atherosclerosis. Obstruction of the nerve feeding vessels by atherosclerosis causes death of nerve bundles and loss of $\operatorname{myelin}^{[46]}$

Immunohistochemical staining has confirmed the observed histological and ultrastructural results. Due to neuronal damage caused by atherosclerosis, activation of Bergmann astrocytes were seen as increased GFAP expression. Astrocytes were found to respond rapidly to any threat to the nervous system by developing various neurotoxic substances and further GFAP production. Such results have been used as a protein marker for astrocytosis ${ }^{[4]}$. The observed features of reactive astrocytes in the present research could be due to compensatory mechanism following neurodegeneration. Related neurotoxicity processes were recorded $\mathrm{d}^{[48]}$. Astrocytosis was the key immunohistochemical characteristic observed in the rabbit brain fed with a high diet of cholestero[ ${ }^{[47]}$. Excessive cholesterol may explain astrocytosis by causing rigidity and loss of membrane fluidity in neurons, and cell debris formation. The developed debris function as antigen and activate the gliosis and inflammatory response ${ }^{[49]}$. Astrocytes had been involved in the neuronal homeostasis cycle, and activation of glial cells may result as a secondary mechanism of cell death or neuroprotective response ${ }^{[47]}$. Similar findings have been reported previously by ${ }^{[50]}$ who observed GFAP up-regulation in brain ischemia and necrosis after injection of cholesterol into internal carotid artery of rats.

The atherosclerotic community result of immunohistochemical staining has shown strong positive reaction for COX-2 in the current analysis. This pathogenic COX-2 effect is caused by inflammation -mediated injury ${ }^{[51]}$. Similarly ${ }^{[52]}$ observed that COX-2 is markedly up-regulated in many brain pathological conditions, consistent with both in vitro and in vivo inflammation and cytotoxicity. Multiple neuropathologies as chronic neurodegenerative diseases associated with high positive COX-2 expression.
High expression of COX-2 is adaptive response in several conditions as inflammatory diseases and oxidative stress ${ }^{[33]}$.

PCNA is a nuclear protein, composed of $40 \%$ cyclin-D and cyclin-dependent kinase, It is strongly associated in the nuclear region where DNA synthesis and repair occurs. It is important in DNA replication and damage repair and it is not only is a cell cycle regulator but it also plays a part in cellular repair processes ${ }^{[54]}$. In comparison with control animals, PCNA immunostained parts of group II (atherosclerotic) revealed negative immune reaction of Purkinje cells and mild positive immune reaction in granule cells. Similarly, ${ }^{[55]}$ found poor expression of PCNA in surviving cells affected by transient cerebral ischemia in brain regions. ${ }^{[56]}$ further claimed that PCNA is important in repair of DNA damage during cell cycle. In addition, ${ }^{[54]}$ demonstrated that altered functional state of PCNA protein in the ischemia-sensitive neurons suggesting that DNA repair processes are affected in these post-mitotic cells following ischemia. He also suggested that impaired DNA repair may play a role in the development of post-ischemic neuronal damage. Also, consistent with our result ${ }^{[57]}$ found that oxidative stress induces DNA damage in both the mitochondrial and nuclear genomes with subsequent week expression of PCNA protein.

The antioxidant enzymes are necessary in preventing and neutralizing oxidative damage caused by radicals. SOD and CAT are major protection factors against free radicals ${ }^{[58]}$. The present biochemical study showed that feeding high cholesterol diet induced reduction of CAT and SOD and significant increase of MDA when compared to control group. In accordance with our findings ${ }^{[45]}$ stated that hypercholesterolemia enhances oxidative stress development and increases LPO through marked elevation in plasma MDA levels. These findings were consistent with earlier work that showed that cholesterol metabolites are cytotoxic and produce reactive oxygen species (ROS) ${ }^{[59]}$.

In the current research, microscopic light and electron analysis of parts of the atherosclerotic co Q 10 treated group showed that they restored almost their usual general architecture except for a few changes that are still present. Co Q 10 is involved in the elimination and prevention of oxidative stress-induced apoptosis by the reactive oxygen species. It also decreases inflammation and improves neuro-protection. Co Q10 significantly reduces the death of apoptotic cells ${ }^{[60]}$.

The present biochemical analysis of blood showed that high cholesterol diet in rats induced a significant increase in the serum level of both triglycerides and LDL-C while total cholesterol showed a highly significant increase, However, HDL-C significantly reduced.

Serum triglyceride level, LDL-C and total cholesterol showed a substantial decrease in the atherosclerotic $\mathrm{Co}$ Q10 rat, but HDL-C increased when compared with atherosclerotic community. Singh et al.$^{[61]}$ reported that due to inhibition of LDL-C oxidation, Co Q10 decreases lipid levels and increases in HDL-C levels and decreases 
oxidative stress $^{[62]}$. The present decrease in lipid profile values due to prevention hepatic synthesis of cholesterol, transfer of plasma cholesterol to liver, or regulation of lipid utilization $^{[61]}$. Coenzyme-Q 10 supplementation resulted in a significant increase in antioxidant markers while the level of oxidative marker MDA showed a significant decline relative to the atherosclerotic community. Such findings were consistent with preceding work ${ }^{[63]}$.

Co-administering Silymarin in this study soothed the neurotoxic effects of atherosclerosis on the cerebellum. In the group treated with atherosclerotic Silymarin (Group IV), the histological pattern almost identical to the control group was found. Microscopic light and electron analysis of this group's cerebellar cortex of rats revealed a more or less normal picture of Purkinje cells, molecular and granule cell layers. Purkinje cells were arranged in a single row and maintained their distinctive pyriform shape. Silymarin was found, in another study, to inhibit oxidative stress in brains of aged and young rats ${ }^{[64]}$. It greatly inhibit degradation of proteins in animals' cerebral cortex and hippocampus. It was also considered a potent anti-inflammatory agent which modulates the various cells involved in this process ${ }^{[65]}$. Additionally, Silymarin had documented being able to protect microglia and astroglia against oxidative insults ${ }^{[6]}$. Compared to control rats, the morphometric results of atherosclerotic- Silymarin treated group showed no significant changes. ${ }^{[67]}$ Claimed that Silymarin had various mechanisms as an antioxidant; by direct free radical scavenging, through prevention development of free radicals, inhibition of particular enzymes and maintaining mitochondrial integrity of electron transport mechanism. Others however indicated that Silymarin's ability to decrease oxidative stress due to its protective effect on function and structure of the mitochondrial system ${ }^{[68]}$.

From all the evidences and findings, we can conclude that atherosclerosis caused by a high cholesterol diet has a deleterious impact and has adversely affected the cerebellar cortex of rats proved by histological, immunohistochemical, biochemical and histomorphometric changes. Cholesterol ratio nutritional knowledge in diet and concomitant administration of Co Q10 or Silymarin will protect against these dangerous effects of atherosclerosis.

On comparison between these two neuroprotectives, it was proposed that Silymarin could be an ideal neuroprotective agent against several conditions where neuronal damage was the product of oxidative stress by inhibiting neurological deficits and apoptosis responses. The treatment may be also a new method for reducing neurological manifestations in high-risk populations.

\section{CONFLICT OF INTERESTS}

There are no conflicts of interest.

\section{REFERENCES}

1. Arenillas J F (2011) :Intracranial atherosclerosis: current concepts. Stroke 42: S20-S23.
2. Lorenzatti AJ, Retzlaff BM (2016): Unmet needs in the management of atherosclerotic cardiovascular disease: Is there a role for emerging anti-inflammatory Interventions? Int J Cardiol; 221:581-586.

3. Moustafa R R, Moneim A A, Salem H H, Shalash A S, and Azmy H A(2013): Intracranial steno-occlusive arterial disease and its associations in Egyptian ischemic stroke patients. Stroke 44: 538-541.

4. Gimbrone MA, García-Cardeña G (2016): Endothelial cell dysfunction and the pathobiology of atherosclerosis. Circ Res; 118:620-636.

5. Besa EminiVeseli, Paola Perrotta, Gregory R.A. De Meyer, Lynn Roth, Carole Van der Donckt,Wim Martinet, Guido R.Y. De Meyer (2017): Animal models of atherosclerosis. European Journal of Pharmacology; 816: $3-13$

6. Li H, and Wong K S (2003): Racial distribution of intracranial and extracranial atherosclerosis. J. Clin. Neurosci.10: 30-34.

7. Splittgerber R (2018):Snell's Clinical Neuroanatomy (Lippincott Williams \& Wilkins, Philadelphia, USA).

8. Spindler, M. M.F. Beal and C. Henchcliffe (2009): Coenzyme Q10 effects in neurodegenerative disease. Neuropsychiatr Dis. Treat. 5: 597-610.

9. Lie L, Liu Y (2017): Efficacy of coenzyme Q10 in patients with cardiac failure: a meta-analysis of clinical trials. BMC Cardio vasc Disord 17(1):196, doi: 10.1186/s12872-017-0628-9.

10. Abd El-Haleem RM, Ossama IY, Raafat N (2014): Protective role of coenzyme Q 10 against high cholesterol diet-induced histological and biochemical changes in cerebellar cortex of adult albino rats. IOSR Journal of Dental and Medical Sciences (IOSR-JDMS); Volume 13, 50-61.

11. Kamal HM, Zein-El-Abedin HM (2018): A histological and immunohistochemical study on the possible protective role of Silymarin on cerebellar cortex neurotoxicity of lactating albino rats and their pups induced by gibberellic acid during late pregnancy and early postnatal period. EJH; Volume 41, 345-371.

12. Hong G, Hui C, Xiaowei C, Wenxiu Z, Shanshan W, Jiyang Y and Zhi C (2019): Silymarin's Inhibition and Treatment Effects for Alzheimer's Disease. Molecules, Volume 24, 1748- 1765.

13. Mansour HH, Hafez HF, Fahmy NM (2006): Silymarin modulates cisplatin-induced oxidative stress and hepatotoxicity in rats. Journal of Biochemistry and Molecular Biology; 39: 656-661.

14. Raza SS, Khan MM, Ashafaq M, Ahmad A, KhuwajaG, Khan A, Siddiqui MS, Safhi MM, Islam F (2011): Silymarin protects neurons from oxidative stress associated damages in focal cerebral ischemia: a behavioral, biochemical and immunohistological study in Wistar rats. Journal of the Neurological Sciences; 309 (1-2): 45-54. 
15. Alzheimer's Association (2016): Alzheimer's disease facts and figures. Alzheimers Dement; 12, 459-509.

16. Castellani, RJ, Plascencia-Villa G, Perry G (2019): The amyloid cascade and Alzheimer's disease therapeutics: Theory versus observation. Lab. Investig. 399-403.

17. Shivane A G (2016): Neuropathology of cerebrovascular diseases. Diagn. Histopathol. 22: 311-317.

18. Oboh G, Bello FO, Ademosun AO, Akinyemi AJ, Adewuni TM (2015): Antioxidant, hypolipidemic, and anti-angiotensin-1-converting enzyme properties of lemon (Citrus limon) and lime (Citrus aurantifolia) juices. Comp Clin Path; 24(6):1395-406.

19. Gage GJ, KipkeDR ,Shain W(2012): Whole animal perfusion fixation for rodents . Journal of Visualized Experiments; 65: 3564.

20. Bancroft Jd and Gamble M. (2013): Theory and practice of histological techniques. 7th ed. 2013, Churchill Livingstone/Elsevier, Oxford:173-179,363-39.

21. Ramos-Vara JA, Kiupel M, Baszier T, Bliven L, Brodersen B, Chelack B (2008): Suggested guidelines for immunohistochemical techniques in veterinary diagnostic laboratories. J Vet Diagn Invest; 20:393-413.

22. Abdel-Dayem MM (2009): Histological and Immunohistochemical Changes in the Adult Rat Testes after Left Experimental Varicocele and Possible Protective Effects of Resveratrol.. Egypt. J. Histol. Vol. 32, No. 1: $81-90$

23. Bakir WA, Yaseen NY, Mohammed ZA, Latef AH, Hasoon HA (2014): Immunohistochemical assessment of Cox-2, and ki-67 expression in gastric cancer. Iraqi J Cancer Med Genet; 7:1-5.

24. Dykstra K, Michael J, Laura E (2003): Biological Electron Microscopy Theory, Techniques, and Troubleshooting effect of vitamin E and vitamin C. Pest Biochem Physiol.; 118:10-18.

25. Kono Y. (1978) Generation of superoxide radical during autoxidation of hydroxylamine and an assay for superoxide dismutase. Arch BiochemBiophys; 186:189-195.

26. Aebi H. Catalase in vitro. Methods Enzymol (1984); 105:121-126.

27. Anoopkumar-Dukie S, Walker RB, Daya S (2001): A sensitive and reliable method for the detection of lipid peroxidation in biological tissuesJ. Pharm.Pharmacol. 53, pp. 263-266CrossRefView Record inScopus.

28. Axelrad JE, Louis ED, Honig LS, Flores I, Ross GW, PahwaR(2008): Reduced Purkinje cell number in essential tremor: a postmortem study. Arch Neurol; 65:101-107.

29. Peat J and Barton B(2005):Medical statistics. A Guid to data analysis and critical appraisal. First Edition. Wiley-Blackwell.113-19.
30. Kim KR, Jang MJ, Choi SW, Woo MH, Choi JH (2006): Consumption of water extract of enzyme-treated S. herbaceapowder showed hypocholestrolemic effect in rat fed high cholesterol diet. J Korean Soc Food SciNutr,; 35:55-60.

31. Gimbrone MA, García-Cardeña G (2016): Endothelial cell dysfunction and the pathobiology of atherosclerosis. Circ Res; 118:620-636.

32. Jang JY, Mi HK, Seok HN, Mi YK (2007): Effects of solid state fermented rice on lipid metabolism and antioxidant status in high cholesterol fed rats. J Med Food; 10(4):608-14.

33. Amin KA, Nagy MA, (2009): Effect of Carnitine and herbal mixture extract on obesity induced by high fat diet in rats. Diabetol. Metab. Syndr. 1: 17.

34. Koya-Miyata, S N, Arai A,Mizote Y, Taniquchi S, Ushio E (2009): Propolis prevents diet induced hyperlipidemia and mitigates weight gain in diet-induced obesity in mice. Biol. Pharm. Bull. 32: 2022-2028.

35. Abd El-Samad AA (2010): Light and electron microscopic study on the effect of aspartame on the cerebellar cortex of male albino rat. Egypt J Histol; 33:419-430.

36. Gartner LP, Hiatt JL (2001):Color textbook of histology. $2^{\text {nd }}$ ed. Baltimore, MA: Lippincott Williams and Wilkins.

37. Ramanathan $M$ and Deshmuk D(2009): Effect of excessive cholesterol and lipopolysacharide on cerebellar neuronal cells in in vitro and protective role of anti-inflammatory drugs. Indian journal of experimental biology. 47: 320-326.

38. EL Shafei MDM, Kamel AMF, Mostafa MEA (2011): Effect of aluminum on the histological structure of rats' cerebellar cortex and possible protection bymelatonin. Egypt J Histol; 34:239-250.

39. Brunk UT, Terman A (2002): The mitochondriallysosomal axis theory of aging: accumulation of damaged mitochondria as a result of imperfect autophagocytosis. Eur J Biochem 269:1996-2002.

40. Mattson MP, Gleichmann M, Cheng A (2008): Mitochondria in neuroplasticity and neurological disorders. Neuron; 60:748-766.

41. Elbeltagy M A, Elkholy WB, Salman AS (2019): Effect of atherosclerosis and the protective effect of the antioxidant vitamin $\mathrm{E}$ on the rabbit cerebellum. Microscopy, 1-10 doi: 10.1093/jmicro/dfz023.

42. Saad El-Dien HMS, EL Gamal DA, Mubarak HA, Saleh SM (2010): Effect of fluoride on rat cerebellar cortex: Light and Electron microscopic studies. Egyptian Journal of Histology; 33: 245 - 256. 
43. Hernandez-Fonseca JP, Rincon J,PedreanezA,Viera N, Arcaya JL, Carrizo E, Mosquera J (2009): Structural and Ultrastructural Analysis of Cerebral Cortex, Cerebellum, and Hypothalamus from Diabetic Rats. Experimental Diabetes Research Volume, Article ID 329632, 12 pages doi:10.1155/2009/329632.

44. Niki E (2011) Do free radicals play causal role in atherosclerosis? Low density lipoprotein oxidation and vitamin E revisited. J. Clin. Biochem.Nutr. 48: 3-7.

45. Lee SM, Park NS, Jin BR, Kang HS, Jung JH, Park EJ (2006): Effects of Paecilomycestenuipes cultivated in egg yolk on lipid metabolism in rats on high fat-cholesterol diet. J Med Food9:214-22.

46. Stokes KY (2006) Microvascular responses to hypercholesterolemia: the interactions between innate and adaptive immune responses. Antioxid Redox Signal, 8(7-8):1141-1151.

47. Sofroniew M V (2014) :Astrogliosis. Cold Spring Harb. Perspect. Biol. 7: a020420.

48. Li L et al. (2008) Protective role of reactive astrocytes in brain ischemia .J. Cereb. Blood Flow Metab. 28: 468-481.

49. Liddelow S A et al. (2017): Neurotoxic reactive astrocytes are induced byactivated microglia. Nature 541: 481-487.

50. Zhang $\mathrm{S}$ et al. (2017): GFAP expression in injured astrocytes in rats. Exp.Ther. Med. 14: 1905-1908.

51. Koki A, Khan NK, Woerner BM, Dannenberg AJ, Olson L, Seibert K(2002): Cyclooxygenase-2 in human pathological disease. AdvExp Med Biol; 507:177-184.

52. Boje KM, Jaworowicz D Jr, Raybon JJ (2003): Neuroinflammatory role of prostaglandins during experimental meningitis: evidence suggestive of an in vivo relationship between nitric oxide and prostaglandins. J Pharmacol Exp Ther; 304:319-325.

53. Minghetti L (2004): Cyclooxygenase-2 (COX-2) in inflammatory and degenerative brain diseases. J Neuropathol Exp Neurol; 63:901-910.

54. Kelman Z (1997): PCNA: Structure, functions and interactions . Oncogene; 14:629-40.

55. Won-Kyu Ju, MS, Keun-Young Kim, BS, Hans-Dieter Hofmann, , Mun-Yong Lee (2000): Selective Neuronal Survival and Upregulation of PCNA in the Rat Inner Retina Following Transient Ischemia. Journal of Neuropathology \& Experimental Neurology, Volume 59, Issue 3, 241-250.

56. Hoege C, Pfander B, Moldovan GL, Pyrowolakis G, Jentsch S (2002): RAD6-dependent DNA repair is linked to modification of PCNA by ubiquitin and SUMO. Nature, 419:135-141.

57. Aitken RJ ,Krausz C (2001): Oxidative stress, DNA damage and the $\mathrm{Y}$ chromosome. Reproduction Oct;122(4):497-506.

58. Ibrahim K,Heba K (2013): Effects of aluminum on rat cerebellar cortex and the possible protective role of Nigella sativa: a light and electron microscopic study The Egyptian Journal of Histology, 36:979-990.

59. Codoñer-Franch PAB,López-Jaén, P,Muñiz, E,Sentandren,Bellés VV (2008): Mandarin juice improves the antioxidant status of hypercholesterolemic children. J. Pediatr. Gastroenterol. Nutr. 47: 349-355.

60. Kunitomo M, Yamaguchi Y, Kagota S, Otsubo K. (2008): Beneficial effect of coenzyme Q10 on increased oxidative and nitrative stress and inflammation and individual metabolic components developing in a rat model of metabolic syndrome. J Pharmacol Sci; 107:128-137.

61. Singh RB,Shinde RK, Chopra MA,Naiz AS, Thakur S (2000): Effect of coenzyme Q10 on experimental atherosclerosis and chemical composition and quality of atheroma in rabbits. Atherosclerosis, 148: 275-282.

62. Attar A M (2010):Hypolipidemic Effects of Coenzyme Q10 in Experimentally Induced Hypercholesterolemic Model in Female Rats. American Journal of Pharmacology and Toxicology 5 (1): 14-23.

63. Modi K D,Santani RK, Goyal PA, Bhatt R (2006): Effect of coenzyme Q10 on catalase activity and other antioxidant parameters in streptozotocin-induced diabetic rats. Biol. Trace Elem. Res. 109: 25-34.

64. Galhardi F, Mesquita K, Monserrat JM, Barros DM (2009): Effect of silymarin on biochemical parameters of oxidative stress in aged and young rat brain. Food and Chemical Toxicology journal; 47(10): 2655-2660.

65. MehriS ,Dadesh Q, Tabeshpour J, Hassani FV, Karimi G, Hosseinzadeh H (2016): Evaluation of the neuroprotective effect of Silymarin on Acrylamide-Induced Neurotoxicity. Jundishapur Journal of Natural Pharmaceutical Products; 11(4): 1-6.

66. Tsai MJ, Liao JF,Lin DY, Huang MC, Liou DY, Yang HC, Lee HJ, Chen YT, Chi CW, Huang WC, Cheng H (2010):Silymarin protects spinal cord and cortical cells against oxidative stress and lipopolysaccharide stimulation. Neurochemistry International; 57: 867-875.

67. Surai PF (2015): Silymarin as a natural antioxidant: An overview of the current evidence and perspectives antioxidants. Antioxidants; 4(1): 204-247.

68. Raza SS, Khan MM, Ashafaq M, Ahmad A, KhuwajaG, Khan A, Siddiqui MS, Safhi MM, Islam F (2011): Silymarin protects neurons from oxidative stress associated damages in focal cerebral ischemia: a behavioral, biochemical and immunohistological study in Wistar rats. Journal of the Neurological Sciences; 309 (1-2): 45-54. 


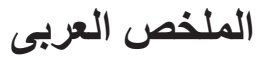

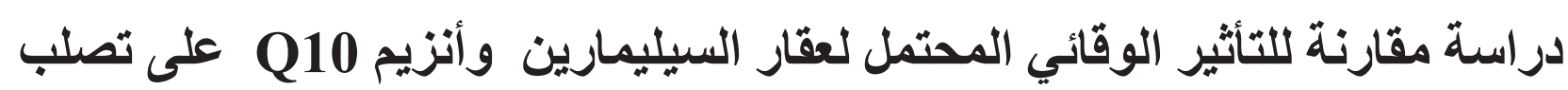

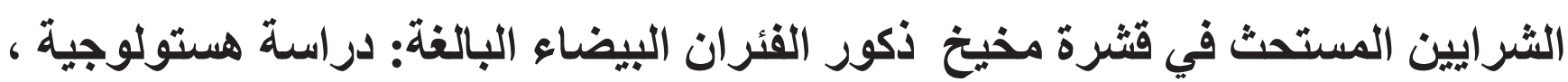 وهستوكيميائية مناعية وبيوكيميائية \\ نادية سعيد بدوي خير وسهام احمد محمد عبد العزيز}

\section{قسم الهستولوجي وبيولوجيا الخلية _ كلية الطب البشرى - جامعة المنوفية}

تصلب الثرايين هو أحد أمراض القب والأوعية الدموية الرئيسية. فهو أحد أكثر أسباب الوفيات في العالم. ويعتبر تصلب الثر ايين مرض التهابى تدريجيى، فتصلب شر ايين المخيخ يؤثر على الكلام و التو ازن و التحكم الحركي الدقيق.

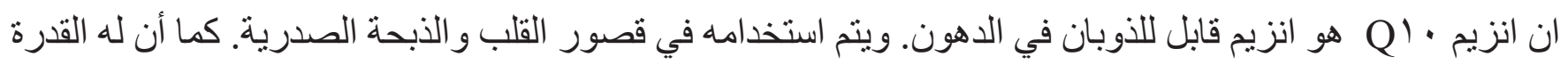
علي التأثير في الطاقة الحيوية الخلوية ومواجهة بعض الأضرار التي تسببها الثوارد التيل الحرة. كما أظهر فعالية في علاج بعض الأمر اض العصبية. أما عقار السيليمارين فهو فلافونويد مشتق من نبات سيليبوم ماريانوم. وقد سجل كدو اء ذهبي في اضطر ابات الكبد وقيم مؤخر ا كعامل حماية عصبية. الهذف من البحث: الهدف من هذا العمل هو مقارنة التأثيرات الوقائية المحتملة لأنزيم · و وعقار السيليمارين علي قشرة المخيخ للجرذان الذكور البيضاء البالغين، الذين يعانون من تصلب الثفن الثر ايين. المواد والطرق: تم استخدام ستون من ذكور الجرذان البيضاء البالغة، وقد قسمت عشو ائيا الي أربع مجمو عات متساوية، البهاء

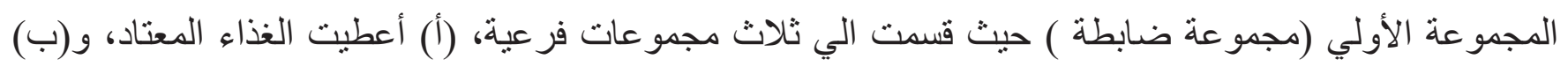

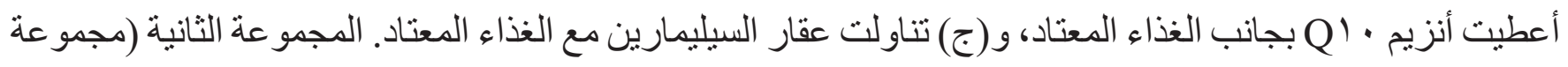

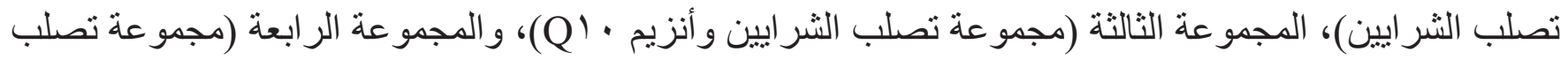

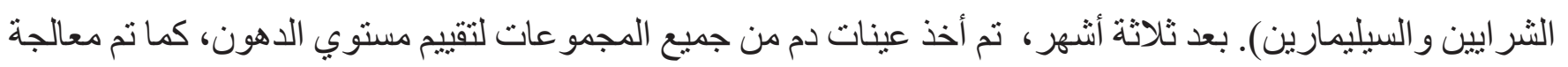

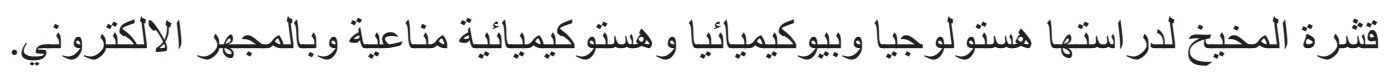
النتائج: أظهرت الفئران التي تعاني من تصلب الثر ايين فقدان وتعطيل خلايا بركينجي، مع احتو ائها علي أنوية داكنة،

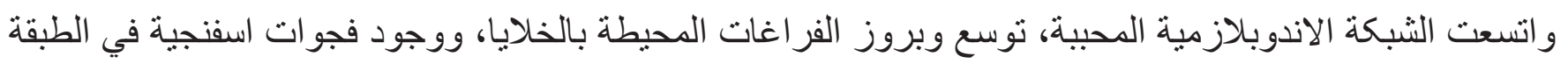

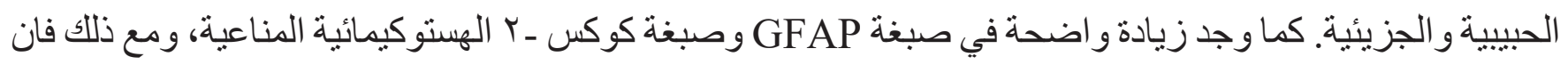

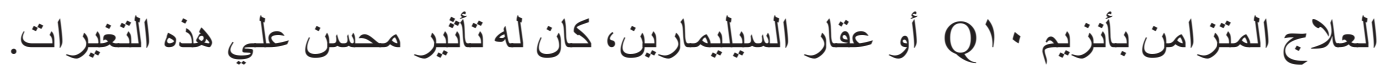

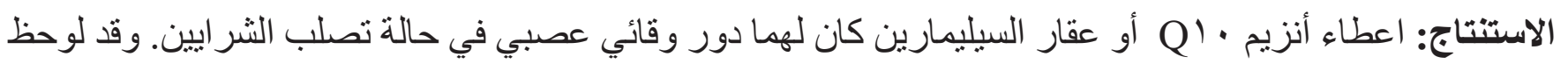
أن عقار السيليمارين قد يكون عامل الحماية العصبية المثالي ونهج جديد للحد من التغير ات العصبية العصبية في الأشخاص المعرضين لخطر الاصدابة بتصلب الثر ايين. 